\title{
PROMOTING HIGH-QUALITY GROWTH THROUGH FINANCIAL REFORM IN THE PEOPLE'S REPUBLIC OF CHINA
}

Yiping Huang, Xun Wang, and Anqian Huang

NO. 43

December 2021
ADB EAST ASIA WORKING PAPER SERIES 
ADB East Asia Working Paper Series

\section{Promoting High-Quality Growth Through Financial Reform in the People's Republic of China}

Yiping Huang, Xun Wang, and Anqian Huang

No. 43 | December 2021
Yiping Huang, Deputy Dean and Sinar Mas

Chair Professor of Finance and Economics,

Peking University

Xun Wang, Associate Research Professor,

Peking University

Anqian Huang, Senior Financial Sector Specialist, East Asia Department, Asian Development Bank 
(C) 2021 Asian Development Bank

6 ADB Avenue, Mandaluyong City, 1550 Metro Manila, Philippines

Tel +632 8632 4444; Fax +63286362444

www.adb.org

Some rights reserved. Published in 2021.

Printed in the Philippines

Publication Stock No. WPS210509-2

DOI: http://dx.doi.org/10.22617/WPS210509-2

The views expressed in this publication are those of the authors and do not necessarily reflect the views and policies of the Asian Development Bank (ADB) or its Board of Governors or the governments they represent.

ADB does not guarantee the accuracy of the data included in this publication and accepts no responsibility for any consequence of their use. The mention of specific companies or products of manufacturers does not imply that they are endorsed or recommended by ADB in preference to others of a similar nature that are not mentioned.

By making any designation of or reference to a particular territory or geographic area, or by using the term "country" in this document, $A D B$ does not intend to make any judgments as to the legal or other status of any territory or area.

This work is available under the Creative Commons Attribution 3.0 IGO license (CC BY 3.0 IGO)

https://creativecommons.org/licenses/by/3.0/igo/. By using the content of this publication, you agree to be bound by the terms of this license. For attribution, translations, adaptations, and permissions, please read the provisions and terms of use at https://www.adb.org/terms-use\#openaccess.

This CC license does not apply to non-ADB copyright materials in this publication. If the material is attributed to another source, please contact the copyright owner or publisher of that source for permission to reproduce it. $\mathrm{ADB}$ cannot be held liable for any claims that arise as a result of your use of the material.

Please contact pubsmarketing@adb.org if you have questions or comments with respect to content, or if you wish to obtain copyright permission for your intended use that does not fall within these terms, or for permission to use the ADB logo.

Corrigenda to ADB publications may be found at http://www.adb.org/publications/corrigenda.

Notes:

In this publication, "\$” refers to United States dollars and "CNY" refers to yuan.

ADB recognizes "China" as the People's Republic of China and "Hong Kong" as Hong Kong, China; "Korea" as the Republic of Korea; and "Peking” as Beijing.

The ADB East Asia Working Paper Series is a forum for stimulating discussion and eliciting feedback on ongoing and recently completed research and policy studies undertaken by the East Asia Department of the Asian Development Bank (ADB) staff, consultants, or resource persons. The series deals with key economic and development problems, as well as conceptual, analytical, or methodological issues relating to project/program economic analysis, and statistical data and measurement. The series aims to enhance the knowledge on Asia's development and policy challenges; strengthen analytical rigor and quality of ADB's country partnership strategies, and its subregional and country operations; and improve the quality and availability of statistical data and development indicators for monitoring development effectiveness.

The ADB East Asia Working Paper Series is a quick-disseminating, informal publication whose titles could subsequently be revised for publication as articles in professional journals or chapters in books. The series is maintained by the East Asia Department. 


\section{CONTENTS}

TABLES AND FIGURES iv

ACKNOWLEDGMENTS V v v v

ABBREVIATIONS vi

EXECUTIVE SUMMARY vii

$\begin{array}{ll}\text { I. INTRODUCTION } & 1\end{array}$

II. OVERVIEW OF FINANCIAL DEVELOPMENT AND OPENNESS 2

A. Structure and Development of the Financial Sector 2

B. Financial Integration with the Global Economy 5

III. FINANCIAL REFORM 6

IV. EFFECTS OF FINANCIAL REPRESSION ON ECONOMIC GROWTH
AND INNOVATION

A. Effects on Economic Growth 8

B. Effects of Financial Development on Technological Innovation 10

V. MACRO PRUDENTIAL POLICIES AND FINANCIAL REGULATORY FRAMEWORK 13

VI. RECENT FINANCIAL SYSTEM DEVELOPMENTS 16

A. Development and Regulation of Digital Finance 16

B. Green and Sustainable Financing 20

VII. CONCLUSIONS AND IMPLICATIONS FOR FURTHER FINANCIAL REFORMS 27

$\begin{array}{lr}\text { REFERENCES } & 30\end{array}$ 


\section{TABLES AND FIGURES}

\section{TABLES}

1 Ten Largest Banks in the World, 1996 and 2019

2 Capital Markets in the People's Republic of China, 1993-2019 3

3 Key Dates in Interest Rate Liberalization 4

4 Estimated Effects of Financial Repression in the People's Republic of China 9

5 Main Models Explaining Innovation 12

6 Macro Prudential Policy Toolkit 13

7 Green Bonds Issued by Industry and Sector, 2019

8 Green Bond Finance Investment Areas, 2019

\section{FIGURES}

1 Structure of Aggregate Financing to the Real Economy, 2002-2019 4

2 Financial Repression Index, 1980-2018 7

3 Real Interest Rates, 1980-2019 8

4 Expenditures on Research and Development, 1996-2017 11

5 Index of Financial Supervision Effectiveness, 2005-2015 14

6 Comparative Effectiveness of Financial Supervision Structures 15

7 Transaction Value of Mobile Payments in the People's Republic of China, 2013-2018 16

8 Distributions of Green Credit, 2019

9 Bonds Issued Onshore in the People's Republic of China, 2019

10 Development of Green Public-Private Partnership Projects 25

11 Green Trust Financing, 2013-2018 26 


\section{ACKNOWLEDGMENTS}

This report was produced with financial support from Asian Development Bank Technical Assistance (TA) 9061-REG: Enhancing Governance and Capacity Development as a Driver of Change and ADB TA6687-PRC: Supporting Sustainable Finance and Regional Cooperation. The report was prepared by Yiping Huang, Deputy Dean and Sinar Mas Chair Professor of Finance and Economics at the National School of Development and Director of the Institute of Digital Finance at Peking University; Xun Wang, Associate Research Professor at the National School of Development and Senior Research Fellow of the Institute of Digital Finance in Peking University; and Anqian Huang, Senior Financial Sector Specialist in ADB's East Asia Department. The report benefited from advice from Emma Xiaoqin Fan, Director of the ADB East Asia Department. The report was peer reviewed by Sung Su Kim, Financial Sector Specialist (Inclusive Finance) in ADB's Sustainable Development and Climate Change Department (Financial Sector Group) and Peter C. Rosenkranz, Economist in the ADB Economic Research and Regional Cooperation Department. Junkyu Lee, Chief of Finance Sector Group, and Hanif A. Rahemtulla, Principal Public Management Specialist in ADB's Sustainable Development and Climate Change Department provided valuable support to make this publication possible. 


\section{ABBREVIATIONS}

$\begin{array}{ll}\text { ABC } & \text { Agricultural Bank of China } \\ \text { ADB } & \text { Asian Development Bank } \\ \text { AI } & \text { artificial intelligence } \\ \text { BC } & \text { Bank of Communication } \\ \text { BOC } & \text { Bank of China } \\ \text { CBIRC } & \text { China Banking and Insurance Regulatory Commission } \\ \text { CBRC } & \text { China Banking Regulatory Commission } \\ \text { CCB } & \text { China Construction Bank } \\ \text { CPS } & \text { Country Partnership Strategy } \\ \text { EFS } & \text { (Index of) effectiveness of financial supervision } \\ \text { EQA } & \text { equity assets (in stock) } \\ \text { EQL } & \text { equity liabilities (in stock) } \\ \text { ESG } & \text { environmental, social, and governance } \\ \text { FDI } & \text { foreign direct investment } \\ \text { fintech } & \text { financial technology } \\ \text { GDP } & \text { gross domestic product } \\ \text { I\&G } & \text { China National Investment \& Guaranty Corporation } \\ \text { ICBC } & \text { Industrial and Commercial Bank of China } \\ \text { IPO } & \text { initial public offering } \\ \text { LTV } & \text { loan-to-value ratio } \\ \text { MPA } & \text { Macro Prudential Assessment System } \\ \text { P2P } & \text { peer-to-peer } \\ \text { OFDI } & \text { outwards foreign direct investment } \\ \text { PBOC } & \text { People's Bank of China } \\ \text { PICC } & \text { People's Insurance Company of China } \\ \text { PPP } & \text { PRC }\end{array}$




\section{EXECUTIVE SUMMARY}

The People's Republic of China (PRC) has adopted a gradual and prudential approach to liberalizing its financial system. The result has been the system's rapid development in terms of total financial assets, number of financial institutions, and share of value added in the gross domestic product (GDP). This expansion and evolution have played an important role in the country's tremendous economic growth since the 1980s. There remains room for improvement in terms of the system's quality. As the PRC embarks on high-quality growth under its 14th Five-Year Plan (2021-2025) for National Economic and Social Development, it is imperative to assess the functioning of its financial sector and propose necessary reforms of a strong financial system as a key building block of sustainable, green, and inclusive growth.

This report assesses the PRC's financial system and attempts to shed light on future reform directions. The PRC's financial system is large. Several of its commercial banks operate globally and are among the world's largest. The PRC has performed strongly in establishing financial institutions, growing financial assets, and adapting to economic conditions. However, as the economy transitions to focus on highquality growth, financial reforms need to be deepened. A financial system based on state-owned banks is more vulnerable to government intervention and more likely to support state-owned enterprises (SOEs). This reduces the efficiency in credit allocation across the financial system. Although prudent phased financial reform and liberalization have helped the economy grow in a stable way, the impact of repressive financial policies turned from positive in the 1980s and 1990s to negative in the 2000s. This suggests rising losses in efficiency and the need for continued reforms.

The rise of digital finance and green sustainable finance are the two most important recent developments in the PRC's financial system. The broad access, low cost, and reliable transactions provided by digital finance have created a revolution of financial inclusion and brought major change to people's daily lives and commercial business models. The Government of the PRC has made a sustained effort since 2016 to build and improve the green finance system. What is needed now is policy support to create a favorable institutional environment and infrastructure.

The financial system can play a crucial role in fostering innovation in the PRC, provided further reforms are undertaken. The government should open up its financial markets steadily to both foreign and domestic private capital. In addition, further financial sector development should enhance the importance of direct financing through the expansion of capital markets. Under an improved regulatory mechanism, developing multilayer equity markets could provide financing for the technological advances the country's economic growth and next-step transitioning require. Evidence across the world shows that credit markets from commercial banks generally provide only incremental support for innovation, but equity markets provide the financing for substantial breakthroughs. In this sense, the plan to set up a third stock exchange in Beijing to serve small and medium-sized businesses is a positive step. These steps should be balanced with an improved regulatory and supervisory system. 



\section{INTRODUCTION}

The financial takeoff. When the People's Republic of China (PRC) began its transformative economic reforms at the end of 1978, the country had only one formal financial institution. The People's Bank of China (PBOC) served as both the central bank and the nation's single commercial bank. It accounted for 93\% of the PRC's total financial assets, with rural credit and other cooperatives making up the remaining $7 \%$. In the more than 40 years that followed, the financial sector opened up and developed under major reforms. Today, the PRC's Big Four banks regularly rank among the world's 10 largest. The country's equity and bond markets have also recently joined the ranks of global leaders. The renminbi, the PRC's currency, is included with the United States dollar, the euro, the pound sterling, and the yen in the International Monetary Fund's Special Drawing Rights basket.

Where next? The financial system has generally worked well over the last 4 decades, helping deliver what is popularly described as the China Miracle. In recent years, however, the system's capacity to support economic development and financial stability has weakened. That this could negatively affect the PRC's longer-term growth trajectory raises important questions. What are the main characteristics of the country's financial system? What effects does financial reform have on economic growth, including growth and development through innovation? What are the main challenges and risks confronting the system today, and what financial reforms are necessary to better guarantee financial stability and help sustain the country's high-quality growing prosperity? This report addresses these issues through a careful assessment of the effects of financial development on economic performance in the PRC. This includes an examination of important recent developments in digital and green finance that can advance some of the needed changes and reforms in the financial system.

Strategies and directions. The PRC has embarked on a high-quality growth model rather than an output growth model. The 14th Five-Year Plan (2021-2025) for National Economic and Social Development of the PRC, released in March 2021, promotes harmonious coexistence between people and nature, improves ecosystem quality and sustainability, and facilitates green transformation and development. ${ }^{1}$ To achieve these objectives, the Government of the PRC supports a well-functioning financial system with critical building blocks to direct resources efficiently for high-quality growth. The new PRC Country Partnership Strategy (CPS) of the Asian Development Bank (ADB) is well aligned with the development areas in the 14th Five-Year Plan. ${ }^{2}$ The CPS highlights three strategic pillars, (i) environmentally sustainable development, (ii) climate change mitigation and adaptation, and (iii) aging society and health security. The ADB's financial sector operations will focus on sustainability and innovation, among other areas and strive to support the PRC's transition to a high-quality development model.

1 The State Council. 2021. The 14th Five-Year Plan (2021-2025) for National Economic and Social Development of the People's Republic of China. Beijing.

2 ADB. 2020. People's Republic of China: Country Partnership Strategy (2021-2025). Manila. 


\section{OVERVIEW OF FINANCIAL DEVELOPMENT AND OPENNESS}

\section{A. Structure and Development of the Financial Sector}

Starting from one. The PBOC was the country's only financial institution when the PRC's economic reforms began in 1978. It served as both a central and commercial bank. In 1979, the government separated commercial bank functions from the central bank and established the Bank of China (BOC), the People's Construction Bank of China (later renamed the China Construction Bank, or CCB), and the Agricultural Bank of China (ABC). The operations of the People's Insurance Company of China (PICC) resumed the same year after it was suspended for close to 20 years. The old PBOC was split in 1984 into the Industrial and Commercial Bank of China (ICBC) and the new PBOC, which remained the central bank. The 1990s began with the establishment of the Shenzhen (1991) and Shanghai (1992) stock exchanges.

Soaring growth. Financial reform in the PRC has adopted a gradual, dual-track approach. The government has supported the establishment of a large number of financial institutions, opened up private sector participation, and allowed the entry of foreign participation in various segments of the sector. At the same time, the government has exerted significant control in the banking sector (Huang et al. 2013). The large numbers of banking, insurance, securities, and other financial institutions are impressive. By the end of 2019, the banking sector had 3 policy banks, 5 large commercial banks, 12 national joint-stock banks, 134 city commercial banks, 6 private banks, and 1,262 rural commercial banks. Based on total assets, the PRC's Big Four and its Bank of Communication (BC) and Postal Savings Bank of China are all among the world's largest banking institutions, and the four biggest banks are identified by the Financial Stability Board as "systemically important" at the global level (Table 1). The PRC's financial markets and assets have also grown exponentially. According to the World Development Indicators, ${ }^{3}$ the PRC had a broad money supply (M2) to gross domestic product (GDP) ratio of 199\% at the end of 2018 and ranked third globally only after Hong Kong, China (384\%) and Japan (252\%).

Table 1: Ten Largest Banks in the World, 1996 and 2019

(\$ billion)

\begin{tabular}{|c|c|c|c|c|c|c|c|}
\hline \multicolumn{4}{|c|}{1996} & \multicolumn{4}{|c|}{2019} \\
\hline & Bank & Country & Assets & & Bank & Country & Assets \\
\hline 1 & Deutsche Bank & Germany & 503 & 1 & ICBC & PRC & 4,027 \\
\hline 2 & UFJ Bank & Japan & 501 & 2 & CCB & PRC & 3,377 \\
\hline 3 & Sumitomo Bank & Japan & 500 & 3 & $A B C$ & PRC & 3,287 \\
\hline 4 & Dai-Ichi Kangyo Bank & Japan & 499 & 4 & $\mathrm{BOC}$ & PRC & 3,092 \\
\hline 5 & Fuji Bank & Japan & 487 & 5 & Mitsubishi UFJ Financial & Japan & 3,069 \\
\hline 6 & Sakura Bank & Japan & 478 & 6 & JP Morgan & US & 2,727 \\
\hline 7 & Bank of Tokyo-Mitsubishi & Japan & 475 & 7 & HSBC & UK & 2,558 \\
\hline 8 & Norinchukin Bank & Japan & 430 & 8 & BoA & US & 2,354 \\
\hline 9 & Crédit Agricole & France & 386 & 9 & BNP & France & 2,336 \\
\hline 10 & ICBC & PRC & 374 & 10 & Credit Agicole & France & 2,123 \\
\hline
\end{tabular}

$\mathrm{ABC}=$ Agricultural Bank of China, $\mathrm{Bo} A=$ Bank of America, $\mathrm{BNP}=$ Banque Nationale de Paris, $\mathrm{BOC}=\mathrm{Bank}$ of China, $\mathrm{CCB}=\mathrm{China}$ Construction Bank, HSBC = Hongkong and Shanghai Banking Corporation, ICBC = Industrial and Commercial Bank of China, PRC = People's Republic of China, UK = United Kingdom, US = United States.

Source: The Banker (UK) http://www.thebankerdatabase.com.

3 World Bank. Worldwide Governance Indicators. http://info.worldbank.org/governance/wgi/index.aspx\#home (accessed 19 November 2014). 
Swift climb to the top in equity, debt, and insurance markets. As of the end of 2019, 3,777 companies were listed on domestic stock exchanges (A shares), with a total market capitalization of CNY59.3 trillion (Table 2). This was the second-largest in the world and accounted for $8.5 \%$ of the global total. The total debt issuance rose from CNY4 trillion in 2005 to CNY15 trillion in 2019 (Table 2). The proportion of debt finance in the country's total social financing, which the PRC defines as the total account of financing of nonfinancial enterprises, households, and the government sector from the financial system, increased from $0.4 \%$ in 2002 to $24.4 \%$ in 2019. This constituted the world's thirdlargest debt market. The country's insurance industry also ranked third globally, with total assets of CNY18.3 trillion and gross premium income of CNY3.8 trillion at the end of 2018.

Table 2: Capital Markets in the People's Republic of China, 1993-2019

\begin{tabular}{|c|c|c|c|c|c|c|}
\hline \multicolumn{7}{|c|}{ Equity Markets } \\
\hline Year & $\begin{array}{l}\text { No. Listed } \\
\text { Companies }\end{array}$ & $\begin{array}{l}\text { Investor } \\
\text { Accounts } \\
(000)\end{array}$ & $\begin{array}{c}\text { Market } \\
\text { Capitalization } \\
\text { (CNY billion) }\end{array}$ & $\begin{array}{c}\text { Tradable } \\
\text { Volume } \\
\text { (CNY billion) }\end{array}$ & $\begin{array}{c}\text { Trading } \\
\text { Volume } \\
\text { (CNY billion) }\end{array}$ & $\begin{array}{l}\text { Funds Raised } \\
\text { (CNY billion) }\end{array}$ \\
\hline 1993 & 183 & 8,350 & 353 & 83 & 363 & - \\
\hline 1995 & 323 & 12,940 & 347 & 94 & 404 & - \\
\hline 2005 & 1,381 & 71,890 & 3245 & 1,064 & 3,166 & 101 \\
\hline 2010 & 2,063 & 133,910 & 26,542 & 19,311 & 54,563 & 293 \\
\hline 2016 & 3,052 & 117,410 & 50,768 & 39,340 & 127,235 & 970 \\
\hline 2017 & 3,485 & 133,980 & 56,708 & 44,929 & 112,364 & 869 \\
\hline 2018 & 3,584 & 145,820 & 43,492 & 35,379 & 90,110 & 1,490 \\
\hline 2019 & 3,777 & 160,550 & 59,293 & 48,346 & 127,357 & 2,365 \\
\hline \multicolumn{7}{|c|}{ Debt Markets } \\
\hline & $\begin{array}{l}\text { Debt Issuance } \\
\text { (CNY billion) }\end{array}$ & $\begin{array}{c}\text { Year-End } \\
\text { Trusted Value } \\
\text { (CNY billion) }\end{array}$ & $\begin{array}{l}\text { Government } \\
\text { Bond Issuance } \\
\text { (CNY billion) }\end{array}$ & $\begin{array}{c}\text { Central bank } \\
\text { Notes } \\
\text { (CNY billion) }\end{array}$ & $\begin{array}{l}\text { Financial Debt } \\
\text { Issuance } \\
\text { (CNY billion) }\end{array}$ & $\begin{array}{c}\text { Corporate } \\
\text { Bond Issuance } \\
\text { (CNY billion) }\end{array}$ \\
\hline 1990 & 32 & - & 20 & - & - & 13 \\
\hline 1995 & 181 & - & 151 & - & - & 30 \\
\hline 2005 & 4,218 & 7,340 & 704 & 2,788 & 716 & 205 \\
\hline 2010 & 9,505 & 20,511 & 1,978 & 4,661 & 1,526 & 1,609 \\
\hline 2016 & 14,144 & 64,235 & 9,109 & 0 & 3,943 & 8,224 \\
\hline 2017 & 13,580 & 74,756 & 8,351 & 0 & 4,385 & 5,635 \\
\hline 2018 & 13,668 & 85,730 & 7,828 & 0 & 4,789 & 7,791 \\
\hline 2019 & 15,306 & 97,097 & - & 0 & 5,610 & 1,0706 \\
\hline
\end{tabular}

Sources: China Financial Stability Report, 2016, 2017, and 2020, Wind. https://www.wind.com.cn.

Importance of banks. Banks still dominate the financial market, although their influence has been diminishing. The share of bank (credit) finance (including bank credit, trust loan, entrust loan, and bank acceptance) in the country's total social financing declined from $87.2 \%$ in 2002 to $70.0 \%$ in 2019 (X. Wang 2020). The share of direct (market) finance, including corporate bond and equity financing, increased simultaneously (Figure 1). However, the stock market's role has not grown as quickly as the economy, as reflected by the shrinking stock market share of financing from $4.6 \%$ to $2.9 \%$ over this period.

Steps toward liberalization. Effective liberalization of interest rates is the key to successful financial reform. The PRC's approach to this is similar to the dual-track strategy it has adopted in the reform of product market prices. Specifically, while continuing to regulate deposit and lending rates, the authorities 
Figure 1: Structure of Aggregate Financing to the Real Economy, 2002-2019

(\%)

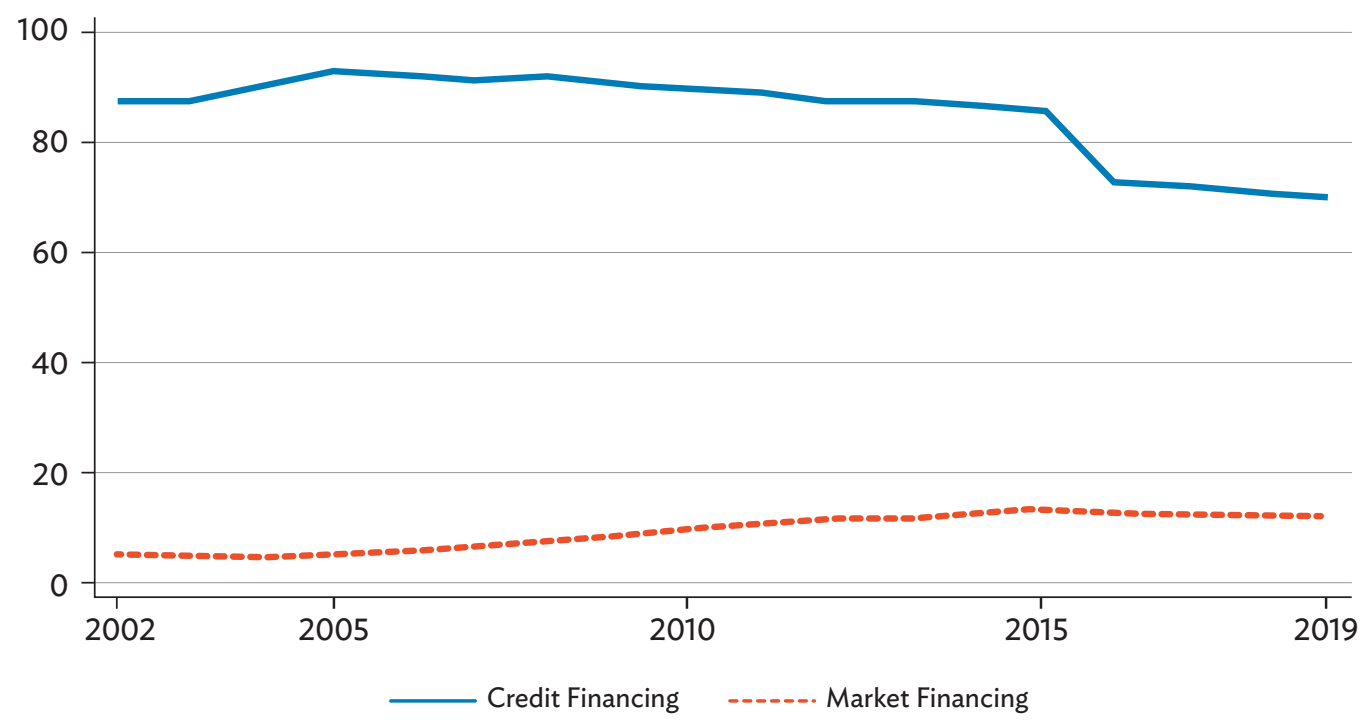

Sources: People's Bank of China and authors' calculations.

began to gradually introduce a market mechanism to liberalize interest rates in the monetary and bond markets starting in the late 1990s (Table 3). The deposit rates remained regulated, while the lending rate was gradually relaxed. The PBOC also gave commercial banks more room to adjust their deposit and lending rates around the base rates it set. The PBOC's ceiling on lending rates and its floor on deposit rates were removed in 2004, and the floor on lending rates and the ceiling on deposit rates removed during 2014-2015. The PBOC has declared that further improvement in monetary policy transmission mechanisms is required and commercial banks need to improve their risk pricing capabilities before they can be allowed to set their deposit and lending rates without government direction.

Table 3: Key Dates in Interest Rate Liberalization

\begin{tabular}{l|l}
\hline Year & \multicolumn{1}{c}{ Key Reform Steps } \\
\hline 1983 & Granted right to PBOC to adjust benchmark lending rate \\
\hline $1998-2004$ & Gradually increased the upper limit on lending rates \\
\hline 1999 & Liberalized interest rate in deposit wholesale market \\
\hline 2000 & Liberalized foreign currency lending rates \\
\hline 2000 & Liberalized foreign currency deposit rates for deposits over \$3 million \\
\hline 2003 & Removed floor on foreign currency deposit rates \\
\hline 2004 & Removed ceiling on lending rates \\
\hline 2012 & Removed floor on deposit rates \\
\hline $2012-2015$ & Increased the lower limit on lending rates \\
\hline
\end{tabular}


Table 3 continued

\begin{tabular}{l|l}
\hline Year & \multicolumn{1}{c}{ Key Reform Steps } \\
\hline 2013 & Removed floor on lending rates \\
\hline 2014 & $\begin{array}{l}\text { Published deposit insurance regulation (draft) } \\
\text { Committed to secure deposits less than CNY500,000 }\end{array}$ \\
\hline 2015 & Removed ceiling on deposit rates \\
\hline
\end{tabular}

CNY = yuan, $\mathrm{PBOC}=$ People's Bank of China.

Source: G. Yi. 2009. On the Financial Reform of China. Beijing: The Commercial Press. http://www.pbc.gov.cn/zhengcehuobi.

\section{B. Financial Integration with the Global Economy}

Large capital inflows through gradually opening up. Capital inflow and outflows have played an important role in the PRC's financial reform process (Huang, Gou, and Wang, 2014). The government allowed domestic enterprises to set up joint ventures with foreign investors in 1980, starting with the Beijing Air Catering Company founded in May of that year. The establishment of the four special economic zones of Shenzhen, Xiamen, Shantou, and Ningbo sped up the pace of foreign direct investment (FDI). The strategy changed in 2013 when the government switched from a positive list of the investment areas where FDI would be accepted to a negative one that allowed all types of access, except for those designated for protection. Since negative lists were first implemented in the Shang Pilot Free Trade Zone in 2013, they have been shortened several times to boost FDI inflows. The government eliminated an equity ratio limit for foreign investors in the banking sector in 2018. The permitted FDI equity ratios in securities, private equity, futures, and life insurance have been raised to $51 \%$. The PRC was identified by the United Nations Conference on Trade and Development as the world's largest destination for FDI in the first half of 2018. It accounted for $\$ 70$ billion of these investments, followed by the United Kingdom ( $\$ 66$ billion) and the United States (US) at $\$ 46$ billion.

Becoming a major foreign investment source. Starting modestly from less than $\$ 1.0$ billion in 2000 , the country has also become an important source of FDI elsewhere in the world. FDI outflows have grown alongside a significant expansion in the PRC's current account surplus and reached $\$ 158.3$ billion in 2018. The PRC share of incoming FDI in the rest of emerging Asia grew from $2.7 \%$ to $55.5 \%$ over the 2002-2018 period. This has made it the largest source of FDI among the developing countries. The growth trend is likely to continue as long as the PRC continues to open up its economy.

Capital account liberalization work in progress. Following Lane and Milesi-Ferretti (2007), Huang and Wang (2018) constructed a volume-based measure of capital account openness. One traditional method is to simply calculate the ratio of the stock of external assets and liabilities to GDP. However, Huang and Wang (2018) also considered a striking and somewhat unique fact about the PRC's external assets. This was the rapid accumulation of foreign exchange reserves that followed the country's entry into the World Trade Organization in 2001. The country's foreign exchange reserves (minus gold) had grown from $\$ 5$ billion in 1981 after economic reforms began to $\$ 158$ billion in 2000, then surged to more than $\$ 3.8$ trillion at the end of 2015 when they accounted for $54.4 \%$ of the PRC's total of external assets. Since huge foreign exchange reserves do not necessarily denote a more liberalized capital account, Huang and Wang (2018) followed Lane and Melesi-Ferretti (2007) to report another measure of capital account openness for the PRC based on equity and FDI stocks (see equation below):

$$
\text { FOPEN }_{t}=\frac{\mathrm{EQA}_{t}+\mathrm{OFDI}_{t}+\mathrm{EQL}_{t}+\mathrm{FDI}_{t}}{\mathrm{GDP}_{\mathrm{t}}}
$$

where EQL (EQA) denotes the stock of equity liabilities (assets) and OFDI (ODI) denotes the stock of foreign direct investment (outward direct investment). 
The PRC's ratio of external assets and liabilities to GDP rose from 0.32\% in 1981 to $43.00 \%$ in 2015. However, compared with high-income economies and upper-middle-income economies, financial integration in the PRC still lagged behind. In 2015, financial integration in the PRC was 160 percentage points lower than the average level of upper-middle-income economies and 279 percentage points lower than the average level of high-income economies. To some extent, this indicates that the PRC's financial market was comparatively less developed. During 2018-2021, despite the increased trade tensions between the PRC and the United States and the pressure on the tech industry's overseas listing requirements among other factors, the pace of financial integration continues to accelerate, partly reflecting the government's commitment to a high-quality growth model.

Easing restrictions. The PRC's financial market is still skewed toward the banking sector overall and the state-owned banks in particular. The PRC has taken several steps since 2019 to ease restrictions on ownership and licenses for foreign financial institutions. This has led to a significant increase in the number of wholly or majority foreign-owned financial institutions operating in the country (Wang 2020). These institutions nonetheless continue to face operational problems, including capital outflows, flexibility of the renminbi exchange rate, and the segmentation of bond markets. However, as the government moves forward with its innovation-oriented development strategy, more equity market and capital mobility liberalization can be expected.

\section{FINANCIAL REFORM}

Financial repression as an anchor to growth. The term "financial repression" was defined when first put forward by McKinnon (1973) as government financial policies that strictly regulate interest rates and foreign exchange, set high reserve requirements on bank deposits, and mandatorily allocate financial resources in the economy. Such repressive financial policies, common in developing countries, are believed to impede financial deepening and lower the overall efficiency of the financial and economic system. As a consequence, financial repression holds back economic growth (McKinnon 1973; Shaw 1973).

The PRC case. Based on the Economic Freedom of the World dataset, Huang and Wang (2018) followed Abiad et al. (2008) to construct a cross-country index of financial repression. The results show that, despite the PRC's gradual liberalization of financial markets, it exhibits a higher degree of financial repression than the averages for the world's high-income and upper-middle-income economies. The PRC ranked as the 24th highest in financial repression among 145 countries for which data was available in 2018. The average index score for the PRC during 2000-2018 was 0.63, which was 30 percentage points higher than the average for high-income economies and 19 percentage points above the upper-middle-income economy average (Figure 2).

Steering through gradual reforms. The PRC pursued a step-by-step strategy of financial reform and liberalization. The pattern was set at the onset of the reform process as the government prepared to initiate a sea change in the country's fundamental economic structure and saw a crucial need to carefully manage the transformation process and related social, economic, and political effects. Compared with the shock therapy approach of transitioning from central planning, the PRC's strategy can be seen as a "growing out of the plan" or "reform without losers" (Naughton 1995). The pairing of continued enforcement of the existing plan framework with the simultaneously staged liberalization of the product market can also be understood as a way to make implicit lump-sum transfers to potential losers or at least compensate them (Lau, Qian, and Roland 2000). As the pricing system began under this strategy to play a role in the information mechanism due to gradual liberalization, state-owned enterprise (SOE) 
Figure 2: Financial Repression Index, 1980-2018

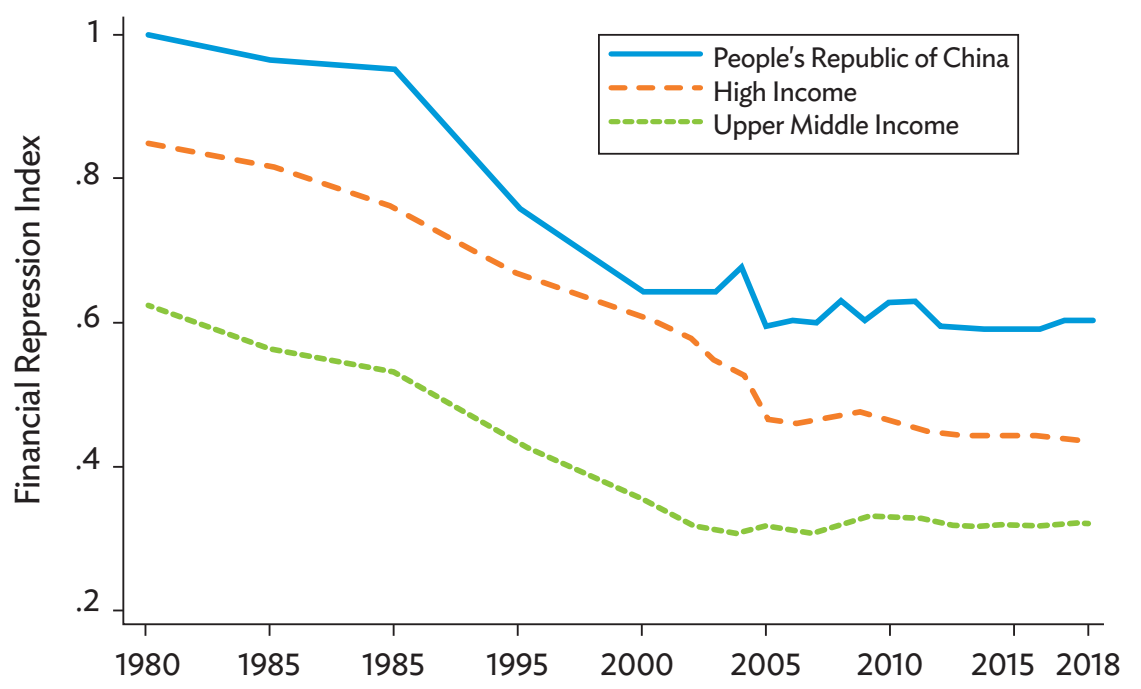

Sources: Economic Freedom of the World Dataset; authors' calculation.

performance began to fall in the face of new competition. With information still imperfect and the market system still underdeveloped, financial policies could be used to allocate bank credit to an SOE identified by market behavior and the pricing system as having promise. This made the state's allocation of financial resources more efficient than it had been before the reforms and paid off with rapid growth known as the China Miracle, as it was first called by Lin, Cai, and Zhou (1995).

Private sector development. The reform strategy did not aim to prevent private enterprises from doing better than SOEs as the market developed. Private enterprises were more sensitive to market dynamics, more efficient in production, and more incentivized to upgrade. This and their lower management and operation costs made them more viable in the market (Huang 2001). In 1995, the government adopted a dramatic reform program called "grasping the big and letting go the small and medium" under which SOEs tended to retreat into essential upstream industries such as energy, finance, transport, and communications. This left downstream industrial areas open for competition by private and foreign enterprises at the end of the 1990s. Demand for private sector production exploded, demand for essential upstream industries followed, and the PRC recorded exceptional rates of economic growth and accumulation of huge foreign exchange reserves in the first decade of this century (Huang et al. 2013).

Interest rates. A repressed financial system is characterized by state intervention to create lower real interest rates that, for example, create lower returns on public savings and essentially reduce public sector financing costs. This distorts the cost of funds and inhibits the allocation of capital and other factors to the more efficient private sector. Huang and Wang (2018) used the difference between the 1 year deposit rates and consumer price index inflation to determine the real interest rate in the PRC during 1980-2019 (Figure 3). The years with negative rates belong to periods of elevated consumer price inflation in the country (1987-1989, 1992-1996, 2007-2008, 2010-2011, and 2016-2019). If inflation in asset prices is also considered, these real interest rates would be much lower. However, the PRC's real interest rates began to converge with market levels since the government started lifting restrictions on interest rates in 2004. In 2019, loan prime-rate reform was launched and this has deepened the PRC's interest rate market reform. 
Figure 3: Real Interest Rates, 1980-2019

(\%)

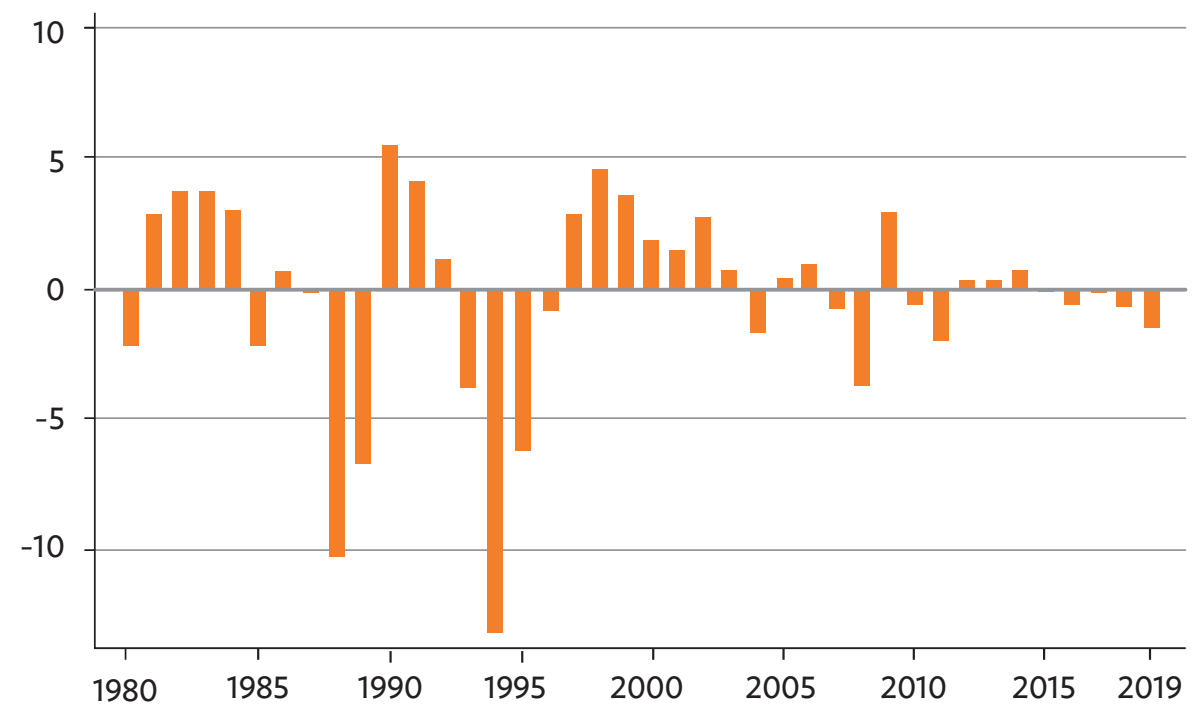

Sources: World Development Indicators, World Bank; authors' calculations.

\section{EFFECTS OF FINANCIAL REPRESSION ON ECONOMIC GROWTH AND INNOVATION}

\section{A. Effects on Economic Growth}

Negative impacts widely accepted. The negative impacts of financial repression on an economy's growth and efficiency are commonly accepted in a large body of literature. Roubini and Sala-i-Martin (1992), for example, presented theoretical and empirical analyses of the negative relationship between financial repression and long-term growth. Pagano (1993) showed that repressive financial policies such as interest rate controls and reserve requirements decrease the assets available for financial intermediation. King and Levine (1993) developed an endogenous growth model to illustrate that financial sector distortions reduced growth by lowering innovation.

Views to the contrary. Despite such broad agreement, other studies have cast doubt on the negative implications of financial repression. Stiglitz (2000) attributed the increasing global frequency of financial crises in recent decades to financial liberalization in the developing world. He argued that, due to the problem of imperfect information, developing countries might be better able to manage their money supply and financial stability and improve Pareto efficiency under policies based on financial restraints (Stiglitz and Weiss 1981; Stiglitz 1994; Hellmann et al. 1997, 2000). The actual influence of financial repression on economic growth is thus unclear and debated. Levine (2005) provided an excellent review of financial development in general and its relation to economic growth. 
Empirical study needed. While the question of whether financial repression inhibits or facilitates economic growth needs to be answered empirically, the net effect is likely to be determined by a combination of the negative effect suggested by McKinnon (1973) and Shaw (1973) and the positive effect highlighted by Stiglitz (1994) and Hellmann et al. (1997, 2000). The outcome of an empirical analysis may be ambiguous and depend on whether one of these effects will dominate the other in a particular circumstance.

Differing effects at different economic stages. Following the literature, Huang and Wang (2011) constructed an aggregate measure of financial repression in the PRC during the 1978-2008 reform period by applying the method of principle component analysis adopted by Laurenceson and Chai (2003) and Ang and McKibbin (2007), among others. The index is normalized into a 0-1 interval, with 1 indicating totally repressed and 0 indicating fully liberalized. The variables used to construct the aggregate index are the annual real deposit rates, interest rate controls, reserve requirement ratios, shares of state-owned banks in total bank loans, shares of the state sector in total outstanding loans, and capital account controls. They then examined the impact of financial repression as indexed on economic growth during this same period. The average of the empirical results for the entire period, as shown in columns 1 and 2 of Table 4, confirm that repressive policies helped economic growth overall, probably due to the implementation of a prudent and gradual liberalization approach in the early reform stages. However, the impact turned from positive in the 1980s and 1990s (Table 4, columns 3 and 4) to negative in the first years of the 2000s (as shown in columns 5 and 6), suggesting rising losses in efficiency.

\section{Table 4: Estimated Effects of Financial Repression in the People's Republic of China}

\begin{tabular}{|c|c|c|c|c|c|c|}
\hline & \multicolumn{2}{|c|}{ Full Sample } & \multicolumn{2}{|c|}{ 1979-1999 } & \multicolumn{2}{|c|}{$2000-2008$} \\
\hline Column & 1 & 2 & 3 & 4 & 5 & 6 \\
\hline \multirow[t]{2}{*}{ Financial repression index } & $0.069^{* * *}$ & $0.167^{* * *}$ & $0.120^{* * *}$ & $0.356^{* * *}$ & $-0.136^{* *}$ & $-0.132^{* * *}$ \\
\hline & $(0.017)$ & $(0.041)$ & $(0.032)$ & $(0.067)$ & $(0.012)$ & $(0.037)$ \\
\hline \multirow[t]{2}{*}{ Investment ratio } & $0.156^{* * *}$ & $0.133^{* * *}$ & $0.136^{* * *}$ & $0.083^{* *}$ & $0.102^{* * *}$ & $0.100^{* * *}$ \\
\hline & $(0.021)$ & $(0.022)$ & $(0.037)$ & $(0.038)$ & $(0.021)$ & $(0.021)$ \\
\hline \multirow[t]{2}{*}{ Trade openness } & $0.013^{*}$ & 0.010 & $0.029^{* *}$ & $0.026^{* *}$ & 0.008 & 0.007 \\
\hline & $(0.008)$ & $(0.008)$ & $(0.012)$ & $(0.012)$ & $(0.012)$ & $(0.012)$ \\
\hline \multirow{2}{*}{$\begin{array}{l}\text { Government } \\
\text { consumption/GDP }\end{array}$} & $-0.258^{* * *}$ & $-0.189^{* * *}$ & $-0.378^{* * *}$ & $-0.183^{* * *}$ & $-0.107^{* * *}$ & $-0.169^{* *}$ \\
\hline & $(0.049)$ & $(0.055)$ & $(0.070)$ & $(0.085)$ & $(0.073)$ & $(0.083)$ \\
\hline \multirow[t]{2}{*}{$\begin{array}{l}\text { Share of SOE in total } \\
\text { output }\end{array}$} & 0.027 & $0.039^{*}$ & 0.004 & 0.039 & $-0.054^{* * *}$ & $-0.039^{*}$ \\
\hline & $(0.020)$ & $(0.020)$ & $(0.028)$ & $(0.029)$ & $(0.022)$ & $(0.023)$ \\
\hline \multirow[t]{2}{*}{ Time Trend } & & $0.002^{* * *}$ & & $0.003^{* * *}$ & & 0.002 \\
\hline & & $(0.0008)$ & & $(0.002)$ & & $(0.014)$ \\
\hline Observations & 750 & 750 & 525 & 525 & 225 & 225 \\
\hline R2 & 0.171 & 0.179 & 0.138 & 0.136 & 0.176 & 0.187 \\
\hline
\end{tabular}

GDP = gross domestic product, $\mathrm{SOE}=$ state-owned enterprise.

Notes: The dependent variable is the provincial real GDP growth rate. Estimation results for primary school student enrollment rates are not reported since they are all insignificant. Numbers in parenthesis are standard errors. ${ }^{* * *}$, ${ }^{* *}$, and ${ }^{*}$ indicate $1 \%, 5 \%$, and $10 \%$ level of significance respectively.

Source: Y. Huang and X. Wang. 2011. Does Financial Repression Inhibit and Facilitate Economic Growth: A Case Study of China's Reform Experience. Oxford Bulletin of Economics and Statistics. 
Benefits in the 20th century. The positive effects of financial repression in the PRC in the 1980s and 1990s are consistent with the Stiglitz argument (Stiglitz and Weiss 1981; Stiglitz 1994; Hellmann et al. 1997, 2000). The market mechanism was underdeveloped during these early stages of the country's new direction in economic development. The government could use repressive financial policies to directly allocate limited financial resources away from household consumption and into investment. This facilitated economic growth and achieved Pareto improvements in the short run with the living standards and welfare of most people in the country improving. However, the cost of financial repression grows over time (as discussed below).

Negative economic impacts from 2000 on. That financial repression began to have a negative effect on economic growth for the period of 2000-2008 indicated in Table 4 supports the hypothesis of McKinnon (1973) and Shaw (1973). As improvements in market conditions and information from gradual government reforms accumulated, efficiency loss grew and turned the net effect of financial repression around. While more efficient private sector small and medium-sized enterprises (SMEs) faced difficulties obtaining funding from the traditional financial sector, the continued allocation of more financial resources to comparatively inefficient SOEs presents an increasingly heavy drag on the efficiency and growth of the economy.

\section{B. Effects of Financial Development on Technological Innovation}

Financing technological progress. One criterion for evaluating the development of the PRC's financial sector is the extent to which it can support technological innovation. This is especially the case now when the government has transitioned from an investment-driven to a consumption- and innovation-driven model for further economic development. Both theory and evidence show that factor inputs cannot continuously support long-term growth due to supply constraints. Innovation, including innovation based on technological advancements, is fundamental to sustaining long-term growth and per capita income growth.

Financial support critical to innovation. Few firms have the internal resources to fully fund innovation, which is commonly measured by gross investment in research and development (R\&D), and by the numbers of patents granted. R\&D, innovation's main input, generally requires long-term investments that are much less flexible than those of capital expenditures and are often determined by regulation and science ( $\mathrm{Li}$ 2011). When funding runs out, R\&D projects have to be suspended, which can significantly (i) reduce an enterprise's value by precluding the benefits innovation would bring and (ii) damage both the firm's and the overall economy's technological progress. Therefore, the need for the financial sector to provide external support becomes critical to innovation at both levels.

Growing role for research and innovation, but investment still lagging. The PRC's R\&D to GDP ratio grew steadily during $1996-2017$ from $0.56 \%$ to $2.12 \%$. This was still 0.7 percentage points below the same ratio in the US, and 1.1 percentage points behind that of Japan (Figure 4). For 2020, it was reported that the total R\&D expenses surpassed $2.40 \%$ of GDP. ${ }^{4}$ This trend suggests that the PRC has been devoting more resources to R\&D and will likely catch up to other advanced economies in the coming years and the PRC's financial system should support elevated R\&D investment requirements to help restructure its economy.

4 CNBC. 2021. China spending on research and development to rise 7\% per year in push for major tech breakthroughs. 
Figure 4: Expenditures on Research and Development, 1996-2017

(\% of GDP)

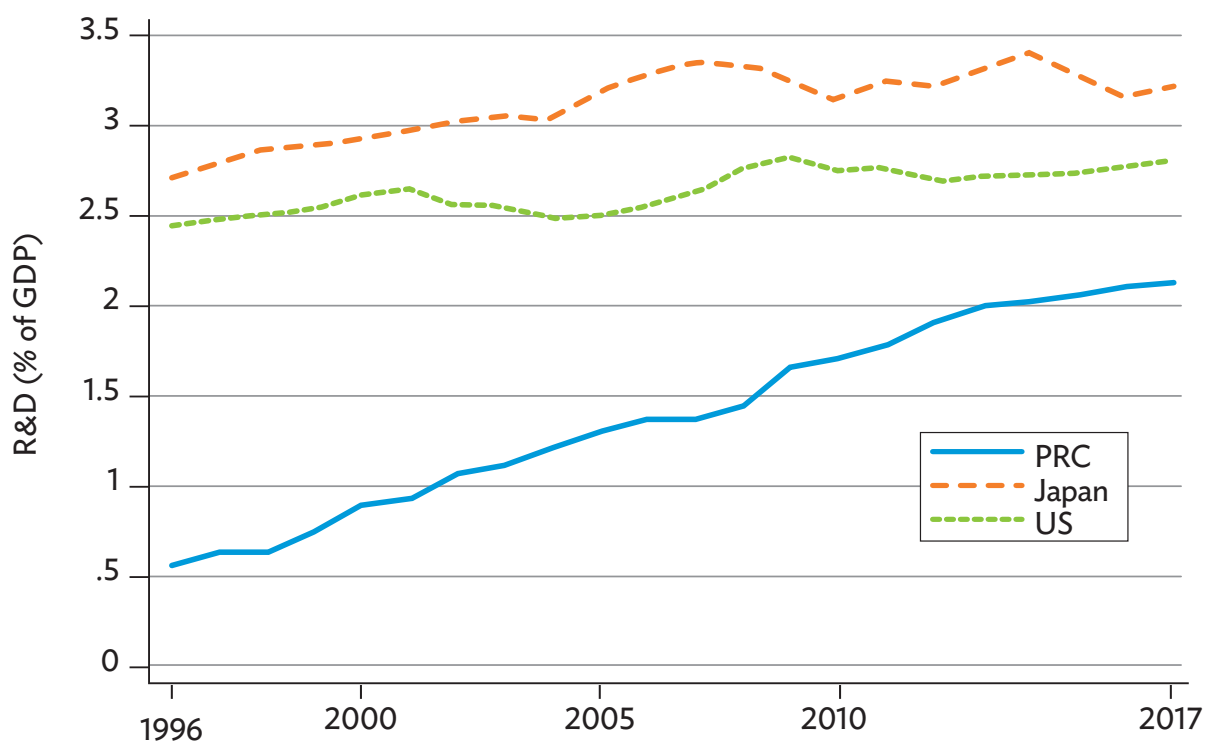

GDP = gross domestic product, PRC = People's Republic of China, R\&D = research and development, US = United States. Source: World Development Indicators.

The question of where funding will come from. Whether the PRC's financial structure can do more to facilitate technological innovation in the coming decades is an important question. Because of the high uncertainty and failure rates involved, the financial development literature suggests that the credit and equity markets could play different roles in determining external financial costs. This impacts innovation. Brown et al. (2013) show that the credit market has a modest impact on fixed investment and no impact on $R \& D$, but better access to stock market financing would lead to a comparatively higher long-term return from R\&D investments, while not being important to fixed capital investment. Similarly, Hsu et al. (2014) show that, in financially dependent industries, equity market development will promote innovation, while credit market development will discourage it.

Equity market advantages versus credit market disadvantages. Equity markets would seem to offer several advantages over credit markets in financing innovation. First, an enterprise seeking support need not provide collateral because equity investors are confident they will share in all the upside returns (Brown et al. 2009). Second, the function of producing information in the equity market would be particularly useful to investors, who could extract information from equilibrium prices (Levine, 2005) to determine the investment's worth. Third, equity markets provide feedback to equity prices, which give investors a reference to the market valuation and growth potential. In contrast, credit markets, including banks, have reasons not to support innovation due to the increasing risk from unstable cash flows and limited collateral. In addition, the feedback effect is absent in credit financing.

Different financing modes for different innovation types. The apparent advantages and disadvantages aside, several countries with bank-based finance systems have performed well by basic innovation measures. Germany and Japan account for a large share of the patents filed in the US Patent and Trademark Office. The PRC's patent count has been growing rapidly for 3 decades. Therefore, credit and equity markets could promote different types of innovation, including two types of patents, invention 
patents and utility model patents. Invention (or utility) patents represent substantive and sometimes radical innovations and they are granted for major inventions and discoveries in technology. Utility model patents, which are primarily granted for modifications and refinements to existing technology and products, represent marginal improvements and incremental innovation.

Table 5: Main Models Explaining Innovation

\begin{tabular}{l|c|c|c}
\hline \multicolumn{1}{c}{} & \multicolumn{2}{c}{ Dependent Variable } \\
\cline { 2 - 4 } Main coefficients & All Patents (1) & Utility Patents (2) & Models (3) \\
\hline Creditct-1*EFDi & $-0.026^{* * *}$ & $-0.027^{* * *}$ & $(0.012)$ \\
\hline & $(0.005)$ & $0.005)$ & -0.007 \\
\hline Equityct-1*EFDi & $0.012^{* * *}$ & $(0.003)$ & $(0.005)$ \\
\hline Country-Industry controls & $(0.003)$ & & $0.071^{* * *}$ \\
\hline VA_Sharecit-1 & & $(0.029)$ & $(0.040)$ \\
\hline Country-Year FE & $0.176^{* * *}$ & Yes & Yes \\
\hline Industry-Year FE & $(0.029)$ & Yes & Yes \\
\hline Observations & Yes & 6,300 & 6,279 \\
\hline Adj-R2 & 6,300 & 0.916 & 0.595 \\
\hline
\end{tabular}

EFD = external financial dependence, $\mathrm{FE}=$ fixed effects, $\mathrm{VA}=$ value added.

This table reports results of regression analyses in which the dependent variable is patent, invention patents and utility patents, scaled by the corresponding sum of patents in the same SIC industry in each year respectively. Our main sample is an unbalanced panel of 5,286 observations on 20 manufacturing industries with two-digit SIC codes between 20 and 39 in 58 countries including developed and emerging and developing economies between 1990 and 2016. VA_Share ${ }_{c i t}$ denotes the share of industry i's value added in country $c$ in year $t-1$. Heteroscedasticity-robust standard errors reported in parentheses are clustered at the country-industry level. ${ }^{* * *} \mathrm{P}<0.01,{ }^{* *} \mathrm{P}<0.05$, and ${ }^{*} \mathrm{P}<0.1$.

Source: X. Wang. 2020. Access to Finance and Innovation. Working Paper. Beijing: Peking University National School of Development.

Equity markets needed for major innovations. The results in Table 5 verify our argument that credit markets are likely to play a positive role in financing the kind of incremental innovation associated with utility model patents, while equity markets provide better support for the major and radical innovations for which invention and utility patents are granted. Moreover, neither market does well in the other's area of strength. These results suggest that the PRC should eliminate restrictions and develop multilayer equity markets to achieve the innovation-powered economic growth structure it seeks to build.

Enhancing the importance of direct financing. The PRC's financial market is still dominated by the banking sector. The market for direct financing, such as via equity investments to and bond purchase from enterprises, is relatively less developed. The share of bank financing, including bank credit, trust loans, entrust loans, and bank acceptances, in the country's total social financing declined from $87.2 \%$ in 2002 to $70 \%$ in 2019 . At the same time, the proportion of direct financing, including corporate bonds and equity financing in the country's total social financing, increased from 5.0\% in 2002 to $12.3 \%$ in 2019 (Wang 2020). However, the share of financing from the stock market dropped from $4.6 \%$ in 2002 to 2.9\% in 2019. Looking forward, to facilitate major innovations, the PRC should further eliminate restrictions in equity markets and promote the development of multilayer equity markets. Equity markets, including stock markets, venture capital and private equity funds, are important for substantive innovation and development in the real sector. The PRC should further reduce administrative interventions in stock 
markets and transform the approval-based initial public offering (IPO) system to a registration-based system. Improving the exit mechanism could enhance liquidity and efficiency in equity markets. The plan to set up a third stock exchange in Beijing to serve small and medium-sized businesses is a positive step.

\section{MACRO PRUDENTIAL POLICIES AND FINANCIAL REGULATORY FRAMEWORK}

Credit and asset price growth a target of macro prudence. Regulatory authorities in many countries have responded to boom-bust cycles in credit and asset prices by adopting macro prudential policies for countercyclical adjustments. The tools frequently include time-varying loan-to-value (LTV) ratios, limits on credit growth in risky sectors, capital and provision requirements, and caps on the debt serviceincome ratio. Growth in housing prices and housing and domestic bank credit have often been the target for such macro prudential policies due to their role in financial boom-bust cycles (Akinci and OlmsteadRumsey 2017). Hence, scholars usually assess the effectiveness of these macro prudential policies by investigating how well they restrain growth in credit and asset prices.

Toolkit development. The PRC's macro prudential policies began with the introduction of a time-varying LTV ratio for the real estate sector in 2003. The dynamic adjustment mechanism of the differential reserve requirement, initiated by the central bank in 2010, has since been upgraded and become the macro prudential assessment (MPA) system. In 2020, the central bank (PBOC) worked with the China Banking and Insurance Regulatory Commission (CBIRC) to establish a countercyclical capital buffering mechanism for the banking system (Table 6).

Table 6: Macro Prudential Policy Toolkit

\begin{tabular}{l|l}
\hline Authorities & \multicolumn{1}{c}{ Policy Instruments } \\
\hline PBOC & Dynamic Adjustment of Differential RRR \\
PBOC, CBIRC & Time-varying LTV ratios \\
PBOC, CBIRC & Countercyclical capital buffer \\
PBOC, CBIRC & Capital surcharge for SIFls \\
PBOC, CBIRC & Early warning system \\
CBIRC & Dynamic provision requirement \\
CBIRC & Leverage ratio requirement \\
CBIRC & Enhancing supervision for SIFls \\
CBIRC & Capital conservation buffer \\
CBIRC & Liquidity surcharge \\
\hline
\end{tabular}

CBIRC = China Banking and Insurance Regulatory Commission, LTV = loan-to-value ratio, PBOC = People's Bank of China, $\mathrm{RRR}=$ required reserve ratio, SIFI = systemically important financial institution.

Sources: B. Wang and T. Sun. 2013. How effective are macroprudential policies in China? International Monetary Fund Working Paper.; and Authors' collation. 
Prudential tools used combined with monetary and regulatory ones. The PRC's macro prudential policies often combine with monetary policy and regulatory tools to influence bank lending. After the central government reversed aggressive credit policies to normal levels in 2010, the China Banking Regulatory Commission (CBRC) issued a regulation restricting the expansion of loans by commercial banks to such industries as real estate and steel, which were beset by overcapacity risks. ${ }^{5}$ This regulation has been used to control rising asset prices alongside macro prudential policies like the time-varying LTV ratio. The MPA system works to ensure that bank credit growth is steady and appropriate by linking the supply of credit to the capital ratios of financial institutions and the rate of economic growth. The PRC has adopted what have been called the twin pillars, monetary and macro prudential policies, in its operational framework to curb credit and asset price booms and prevent systemic financial risk.

Effectiveness of financial supervision. An index to measure the effectiveness of financial supervision (EFS) developed by Huang and Wang (2017) shows that EFS began to decline in 2013 (Figure 5). This was likely due to a gap in the regulatory system to fully cover the rapid growing nontraditional financial operations, and the impetus provided to some institutions by the current financial system structure and the post-2010 supervision and monetary supply tightening to engage in regulatory arbitrage. This indicates that more restrictive macro prudential supervision can lead to an increase rather than a decline in credit growth and asset prices. From 2015-2021, the level of financial supervision (and regulation) continues to improve, for example, by closing the loopholes in tech and nontraditional industries. This will likely improve financial market stability and continued development. The expanded direct financing volume should also support the PRC's long-term economic growth prospect.

Figure 5: Index of Financial Supervision Effectiveness, 2005-2015

( 1 is perfect effectiveness and 0 is perfect ineffectiveness)

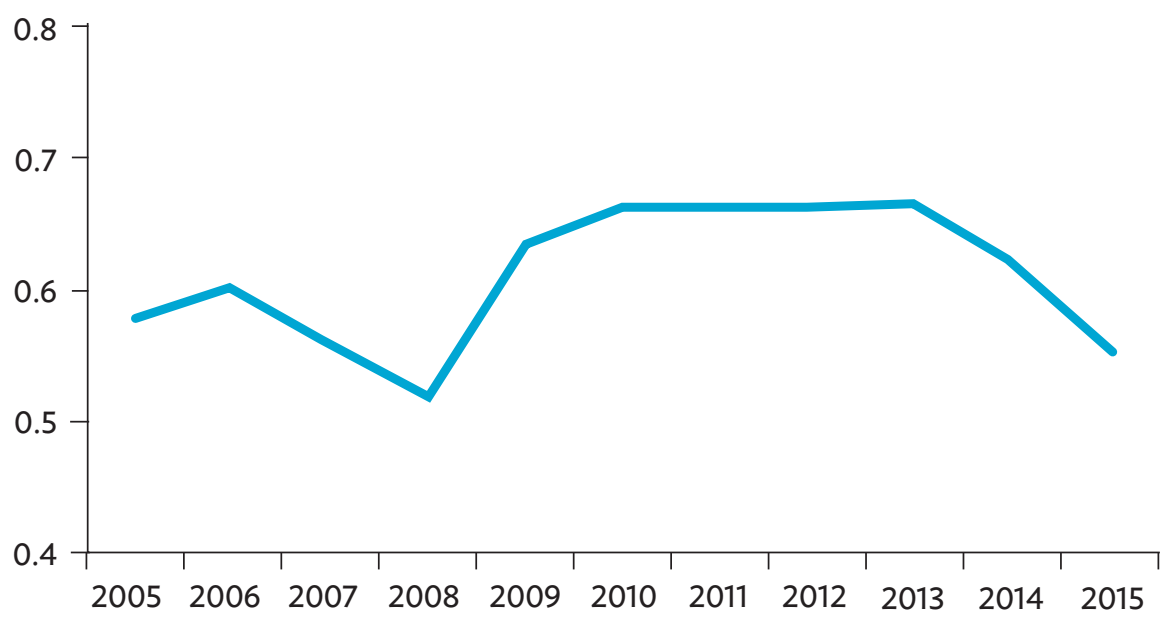

Source: Y. Huang and X. Wang. 2017. Building an Efficient Financial System in China: The Need for Market Discipline. Asian Economic Policy Review.

5 Nevertheless, the real estate industry continues to be highly leveraged financially, as recent events regarding Evergrande and other property companies have shown. 
Consumer protection. A weakness in the current PRC financial supervision system is consumer protection. Financial markets need to be honest and effective to give consumers a fair deal, but this is often not the case when financial conduct is not properly regulated. Financial service firms harm consumer interests by increasing the complexity of their products and impairing the integrity of the financial system through unfair competition. The high EFS performance of the financial systems of Australia, the Netherlands, and some other countries are mainly attributed to their so-called "twin peaks" regulatory framework, under which one regulator is responsible for macro prudential regulation and the other for market conduct and consumer protection (Figure 6$)^{6}{ }^{6}$

Government moves to improve regulation. The Government of the PRC has recognized the importance of reforming the regulatory framework and how regulation is carried out. The Financial Stability and Development Committee of the State Council was set up in 2017 to coordinate regulatory policies. The central government merged the China Banking Regulatory Commission and the China Insurance Regulatory Commission in 2018 to form the CBIRC. The government has stated that regulatory reforms aimed at better addressing the systemic risk and the need for financial stability will continue.

\section{Figure 6: Comparative Effectiveness of Financial Supervision Structures}

( 1 is perfect effectiveness and 0 is perfect ineffectiveness)

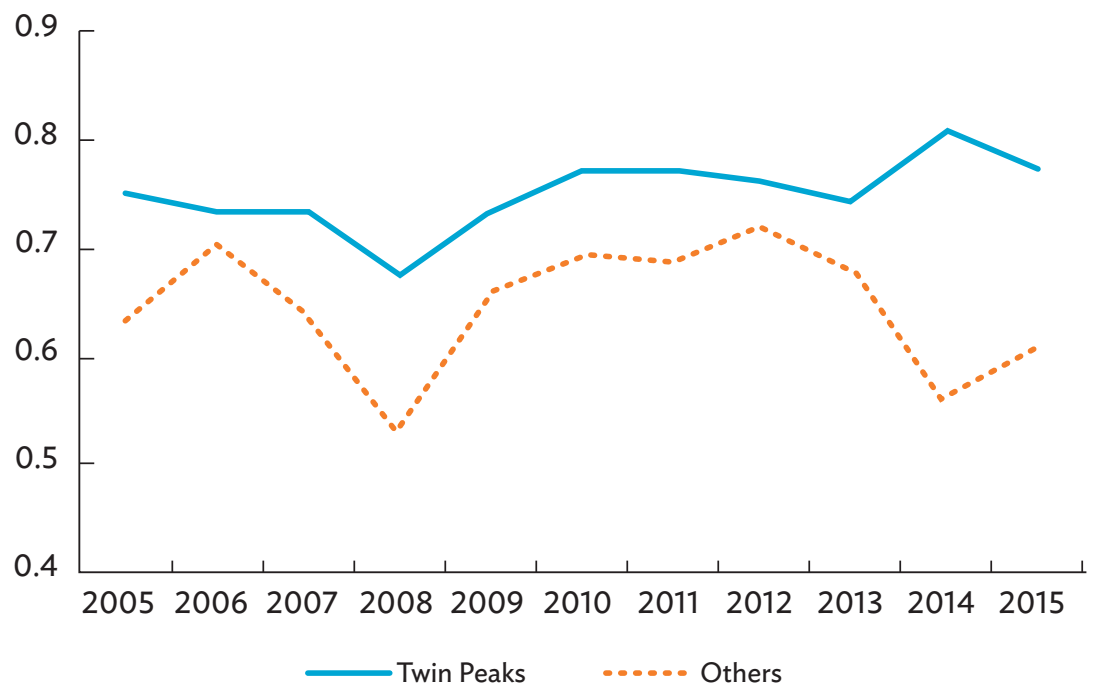

$\mathrm{EFS}=$ (Index of) effectiveness of financial supervision.

Source: Y. Huang and X. Wang. 2017. Building an Efficient Financial System in China: The Need for Market Discipline. Asian Economic Policy Review.

6 A. Godwin, L. Guo, and I. Ramsay. 2016. Is Australia's “Twin Peaks” System of Financial Regulation a Model for China? "The twin peaks model is considered to have a number of advantages. First, the two peak regulators are more likely to have dedicated objectives and clear mandates to which they are exclusively committed. Second, there is minimal danger that one aspect of regulation, such as prudential regulation, will come to dominate the regulatory landscape. Regulatory culture, which encompasses the attitudes, policies and practices adopted by regulators in fulfilling their objectives, can be fostered depending on the function of the regulator and the culture that it needs to perform its role effectively. This avoids the issue of having multiple cultures under the one roof, as might be the case with a super-regulator where different cultures arise as a result of the different regulatory objectives. Third, the model may be better adapted to keeping pace with the growing complexity of financial markets and the continuing rise of financial conglomerates. Finally, the twin peaks model may avoid an inherent conflict of interest in having a super-regulator." 


\section{RECENT FINANCIAL SYSTEM DEVELOPMENTS}

\section{A. Development and Regulation of Digital Finance}

\section{The Rise of Digital Finance}

The growth and promise of financial technology (fintech). Inclusive digital finance, initiated mainly by such private fintech companies as Ant Financial and Tencent, is a recent innovation in the PRC. One of the first and most successful examples is the mobile payment system. By 2013, only 4 years after Ali Pay and WeChat Pay, mobile payments had been adopted by over $70 \%$ of the country's adult population, including $66.5 \%$ in rural areas. Mobile payment in the PRC differs in important ways from mobile money systems in some other developing countries such as M-PESA in Kenya and South Africa that need a network of agents to provide cash-in and cash-out services. Mobile payment systems in the PRC function as electronic-wallets (e-wallets) that can safely store and receive funds digitally and make easy payments by scanning a QR code. Purchasing power can be transferred in real-time to others with accounts.

Explosive growth. The use of digital finance has exploded in the PRC, especially for mobile payments. The number of active users of Alipay increased from a little over 100 million in 2013 to 900 million in 2018, while the figure for WeChat Pay went from about 350 million to 1.1 billion. Total transaction values jumped from CNY14.5 trillion to CNY277.4 trillion over the same period, growing at $80 \%$ a year (Figure 7). Mobile payment transactions jumped by $61 \%$ in a single year to 60.5 billion in 2018 . The share of mobile payments in total non-cash payment value rose during $2013-2018$ from less than $1.0 \%$ to $7.4 \%$ in 2018, and the share of mobile payments in the overall number of non-cash payment transactions was up to $27.3 \%$ from only $3.3 \%$. Some mobile payment platforms have branched out into monetary funds, credit provision, financial management, credit referencing, and big data.

Figure 7: Transaction Value of Mobile Payments in the People's Republic of China, 2013-2018 (CNY trillion)

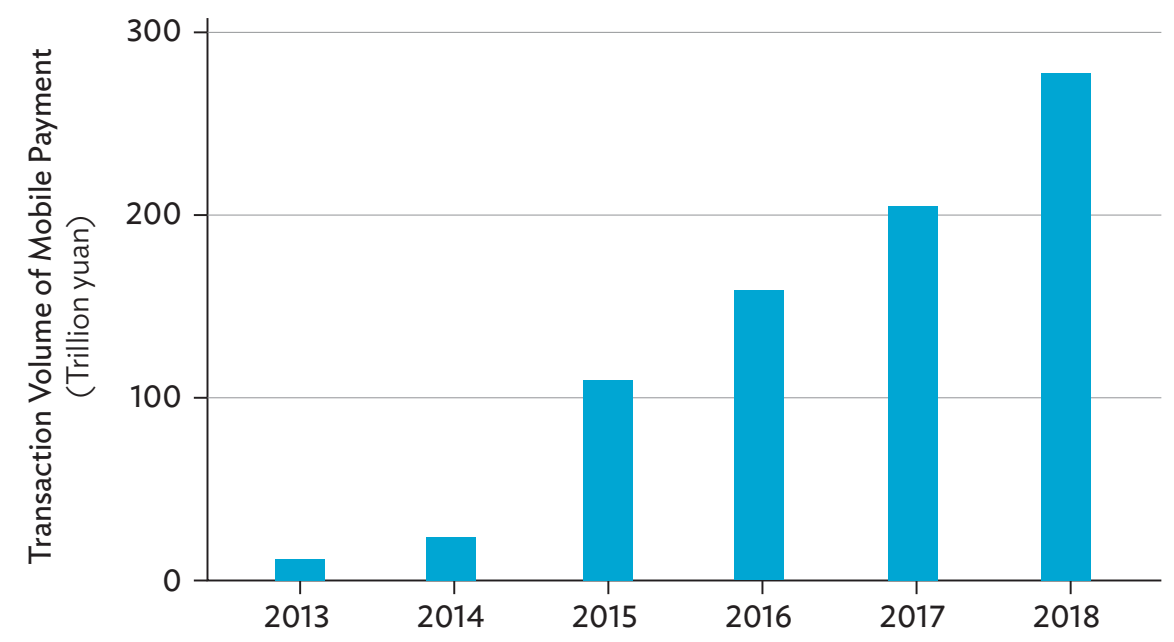

CNY = yuan.

Sources: Census and Economic Information Center, People's Bank of China. 
Benefits across multiple fronts. The broad, cheap access to reliable transactions offered by digital finance has created a financial inclusion revolution. Besides changing daily lives and commercial business models, it has been shown by empirical analysis to improve risk-sharing between individuals and their ability to self-insure through savings and reserves. The number and variety of entrepreneurial opportunities have also grown. Digital innovations have expanded the types of financial services and access to them, enhanced customer experience and boosted financial efficiency by reducing costs and better controlling default risks. The value of the new digital finance era was apparent during the coronavirus pandemic when it combined with digital and offline real economic activity to significantly ease the burden on economic development and the everyday lives of people.

Global leader. The PRC has been ranked the number one mobile payment market in the world in terms of transaction volume or service penetration rate from 2015 to 2021. The adult-use rate has been as high as $77 \%$ and was recorded at $67 \%$ in the country's rural areas in 2017 . The PRC's global leadership in this area was illustrated by Ipsos statistics for 2016 when the country's 77\% penetration level could be compared with rates of $48 \%$ in the US, $48 \%$ in Germany, $47 \%$ in the United Kingdom, 38\% in France, and $27 \%$ in Japan.

Major contributions to financial and regional inclusion. Digital financehas proven particularly effective in the PRC in meeting the global challenge to deliver reliable, sustainable financial services, especially payment services, to SMEs and low-income households (Nanda and Kaur 2016; World Bank 2017). Mobile payments have improved financial inclusion in the country by reaching a greater number of SMEs and individuals in remote areas. These developments have narrowed the geographical divide between the populous east and the less developed west. Specifically, there has been a gradual increase in the convergence of mobile payments in the less populous northwestern regions since 2011. Consequently, the geographic divide in accessing mobile payment services between the southeastern and northwestern parts of the country had largely disappeared by 2018.

A large preexisting demand for payment services. Comprehensive technology and digital finance regulatory policy were absent during the initial rapid market development phase of digital payment services. Although the initial motivation for developing Alipay was to create trust between counterparties of buyers and sellers, a much greater gap was there waiting to be filled. When coupled with severe financial repression, the PRC's exceptionally bank-heavy financial system has made achieving financial inclusion particularly challenging. The credit card penetration rate stood at 0.47 cards per person in 2018 , compared with 2.9 per person in the US. Using more traditional card payment services, such as point of sale machines, is often slow, inefficient, and expensive. Most SMEs and low-income individuals had to use cash for their financial transactions. With a high level of smartphone ownership in the PRC, the market immediately embraced mobile payment services when they came online. With withdrawals up to CNY20,000 free of charge and a $0.1 \%$ charge on amounts above that level, over $90 \%$ of the adult population in the PRC's large cities use mobile banking as their main payment method. Cash comes second. Debit and credit cards come third. However, due to its unique development phase, the country's astonishingly rapid growth in mobile payments would be hard for more advanced economies to match according to some experts (Klein 2019).

The favorable legal and regulatory environment. The PRC also provided legislative and regulatory support for mobile payment systems to experiment and grow. The government enacted its law on electronic signatures in 2004, making it possible to sign contracts legally online. The State Council released a series of policy documents beginning in 2005 that supported the development of e-commerce. Strict regulatory restrictions on mobile payment came only in 2010 with the PBOC's promulgation of measures for the administration of payment services for nonfinancial institutions. The PBOC also took the innovative policy step of issuing almost 270 third-party payment licenses. The move spurred mobile payment growth. At the start of 2019, the PBOC became the new custodian of all customer funds deposited by third-party payment groups and tightened control on mobile payment transactions and clearances, which reached CNY1.24 trillion in November 2018. 
Development and adoption of mobile technology. Technological development was necessary to spread mobile payment services and coverage. The high mobile phone penetration rate in the PRC offers tremendous flexibility in terms of the times, places, and ease with which it can be used to make payments, compared to desktop computers. Payment service providers made massive investments to constantly make the user experience better and the service more reliable. Alipay could handle 210,000 payments per second in 2017, up from only about 200 in 2011. The fund-loss rate was also reduced to under one in a million. The adoption of QR codes also brought about revolutionary changes supporting mobile payment usage.

\section{Other Developments in Digital Finance}

Initiatives and mostly progress on four additional digital finance fronts. Besides its advanced standing in digital payments services, the PRC's position among the world's leaders in digital finance has been secured by progress (and marked by some setbacks) in four other main areas where technology has been used to help create greater financial inclusion. These are big tech lending, digital supply chain finance, the digital transformation of commercial banking, and, on the downside, digital peer-to-peer (P2P) lending platforms.

The rise and fall of P2P. The P2P market in the PRC was intended to extend credit to "long-tail" ordinary customers by using big data to distribute risk and set appropriate interest rates. However, P2P platforms proved to be unsuited to this new purpose and often commercially unsustainable. Information between online lenders and borrowers was asymmetrical. Risks were mis-analyzed, interest rates often set unrealistically high, delinquencies underestimated, and collections proved to be expensive or impossible. A long period without close government supervision created moral hazard and an excess of malfeasance on both sides of the transactions. Many customers suffered losses, many P2P enterprises shut down, and government intervention effectively ended the experiment in its original form.

Efficiency of big tech lending boosted by big data. Advances by big tech lenders in the PRC's fintech sector have been powered in part by big data. The growth of these lenders, and their growing contribution to financial inclusion, are enabled by the ability to digitally collect, process, and analyze information to better assess risk. Fintech operators that offer payment services to consumers, such as Ant Financial, have access to real-payment data from social media activity, digital footprints, and other sources that can accurately determine consumer behavior, financial lives, and income streams in setting a borrower's creditworthiness. The assessment tools include machine learning technology and other complex artificial intelligence (AI) algorithms (Gambacorta et al. 2019; Jagtiani and Lemieux 2019). This gives them access to the many individuals in the PRC who cannot get loans from banks due to the country's lack of an established credit registry. Internet-based MYbank has lent CNY2 trillion to 15.7 million small companies. Borrowers apply to the online commercial bank, an Ant Group company, with a few taps on a smartphone to receive their loans within three minutes, if approved. The default rate as of 2019 was about 1\% (Bloomberg 2019). The modest average size of the business loans (CNY10,000) illustrates how fintech banking is making financing in the PRC far more inclusive for the SMEs sector, which has long been underserved by the state-owned banking giants.

Digital supply chain finance. Digital supply chain finance also presents SMEs with valuable new financing opportunities. Using new digital technologies such as the Internet of Things, blockchain, and big data are being integrated with traditional functions of supply chains. Digital supply chain finance is more likely to provide SMEs with prepaid account financing, financial leases for equipment, and financing accounts receivable. Digital technology can effectively monitor assets and verify transactions.

Digital transformation of commercial banking. The PRC's commercial banking sector has also gone digital. The opportunities offered by digital finance include more accurate risk assessment and sound 
credit decisions based on big data, rather than on collateral, existing relationships, and government direction alone. Other factors being equal, including the effects of financial repression and government interventions, these objective measurements could strengthen systemic and macroeconomic stability and financial inclusion. The broad introduction of the digital currency offered by the PBOC, along with the possible development of other central bank digital currencies around the world, would generate even greater momentum for the digitalization of commercial banking and finance in the PRC.

The launch of digital currency or e-CNY. Mobile payments, dominated by Alipay and WeChat Pay, has brought significant convenience to people's daily lives and largely changed people's payment habits. An emerging challenge to mobile payments is the risk of power outages and Internet disconnection. This gave rise to the need to launch e-CNY. e-CNY is a retail central bank digital currency designed to replace notes in retail transactions. The main purpose is to improve financial inclusion and provide safer and cheaper offline services. At this time, competition with existing mobile payment services and banks will probably be limited. Another challenge is whether e-CNY will affect the way big data is collected and analyzed. At this time, the launch of e-CNY is not related to the internationalization of the CNY. Internationalization of the CNY depends on acceptance by international markets and investors.

Finance for everyone no longer just a dream. The swift rise of digital finance in the PRC has been powered by a confluence of factors including technological advances, the popularity and broad uptake of smartphones, the quick emergence of fintech players, the space left by inadequate access to finance for individuals and the private sector, and relatively loose financial supervision. The emergence of the PRC's own big tech platforms and big data, Al, and cloud computing technology have made universal financial inclusion an achievable goal for the first time in the country's history. Each of the PRC's two leading mobile payment service providers, Ant Group and Tencent, now serve about one billion customers, and each of the new big tech lenders provides about 10 million micro enterprise or individual loans each year. The development of digital financial inclusion has not only converged rapidly across regions, but is also impacting entrepreneurship, employment, and income positively, especially in rural areas.

\section{Regulating Digital Finance}

Significant changes on the regulatory environment. In November 2020, Ant Group suspended its dual listing on the Shanghai Stock Exchange and the Hong Kong Stock Exchange. Regulators cited significant issues such as changes in the fintech regulatory environment and Ant Group not meeting the conditions for listing or meeting the information disclosure requirements. In the following months, Alibaba, the parent company, was administratively punished by the State Administration for Market Regulation for abusing its dominant market position. Meituan, another major online platform that specialized in takeaway food ordering, online hotel reservations, and tour group purchasing and ticketing services was investigated on suspicion of monopolistic behavior.

The dangers of poor regulation. The regulatory changes in the PRC reflect the current situation of its digital finance industry. While the PRC is already a global leader in multiple high-tech business sectors including mobile payments, online investment, and digital credit, the regulatory framework has not yet caught up. Although the bright side is more than evident, the difficult pace of digital financial innovation in the PRC has left several outstanding issues unresolved. These include the matters of data ownership, data inequality, and inadequate regulation (Huang et al. 2020). Every new digital finance platform must be subject to financial supervision to protect consumers, maintain financial stability, and maximize financial efficiency. The moral hazard and failures in the P2P lending platform experiment shows what can happen when such supervision is absent or weak. 
New antitrust policies needed for the digital financial industry. Recently, regulatory authorities in the PRC have begun investigating monopolistic practices by the tech industry, such as mobile payments. Because digital technology has the characteristic of wide coverage (such as WeChat Pay and Alipay), once well accepted by consumers, large tech companies have naturally become dominant players in the market. However, market share may not be the most accurate indicator for measuring monopoly. A more appropriate criterion for judging monopolistic practice is contestability, i.e., whether new players can still enter and compete with the existing dominant businesses. In the PRC's digital economy, contestability is obvious. For example, in terms of online shopping platforms, Taobao is the leading platform in e-commerce, followed by Tmall, JD.com, and many others. In recent years, a new platform, Pinduoduo, has quickly surpassed Taobao. In terms of social media, while WeChat is still dominant, it has been facing competition from Weibo. Tik Tok has also been taking market share from other social media platforms. Therefore, given the dynamics in the digital economy, monopolistic practices in the PRC may not be prevalent. Rather, regulatory policies should pay more attention to fair competition and consumer protection rather than antitrust in the narrow sense. These big tech companies will become a major market infrastructure over the coming decades and regulators should not try to control them as they would SOEs, but manage them to prevent associated systemic financial risks.

Keeping up with rapid-fire change and expansion. Keeping up with the explosive growth in digital finance presents a challenge to regulators. New regulatory frameworks for digital finance should follow two principles. First, digital finance, like the traditional financial sector, should be fully incorporated into the financial supervision framework to reduce and manage financial risks, including risks caused by excessive regulatory arbitrage. Second, under consistent regulatory standards, regulatory authorities should actively seek innovations in digital financial supervision to balance efficiency and financial stability. Flexibility and agility will be required in both cases. Digital finance is likely to continue to expand with great speed and take many new forms.

Digital finance entering a new stage. In the past decade, the digital finance industry in the PRC grew rapidly. From 2020-2021, the sector will enter a stage of regulatory supervision and oversight. The major forces driving digital financial innovation come from private sector big tech companies, not publicly-owned SOEs. This needs to be fostered. In addition, traditional financial institutions, including commercial banks, may become the main force of innovation over the coming decades. While the most active subsectors in the past were mobile payments and digital credit, Al could become the new future. In the past, it was mainly based on the consumer Internet to innovate financial services. In the next stage, various Internet of Things, including an industrial Internet, will become the main drivers of digital financial innovation.

\section{B. Green and Sustainable Financing}

The government's major green push. Due to the persistent environmental damage from the rapid industrialization that began in 1990, the PRC has, since 2016, been placing particular attention on developing a green finance system, including environmental, social, and governance (ESG) standards that play such a crucial role in the efficient allocation of resources for green development. The central government has pursued this objective through a top-down promotional approach and local trials. The effort has included building standard systems, undertaking basic theoretical research, policy design, innovations in products and services and international cooperation and exchanges. The PRC has committed internationally to achieve peak carbon emissions by 2030 and carbon neutrality by 2060 . 


\section{Green Credit}

Banking the green leader. Banks are a major provider of green products and services. Although they underwrite green bonds and securitize green assets, their main green finance instrument, and that of the green finance market overall, is currently green credit, defined as commercial bank lending to eligible projects that comply with national green finance standards. Due to the strong compliance measures with government environmental and social regulations, green projects have a higher credit quality and lower default risk than those in many other traditional industry sector projects. The PRC's green credit balance stood at CNY10.22 trillion at the end of 2019. It was up 15.4\% year-on-year, accounted for $10.4 \%$ of all loans to enterprises and public institutions and had grown at a rate 4.9 percentage points higher than this overall lending. The nonperforming ratio of green loans was only $0.73 \%, 1.54$ percentage points below that of corporate loans and 1.13 percentage points lower than the commercial bank ratio.

Impacts already felt. The green credit program was already benefiting the PRC's environment. The government estimated that for 2019 , the loans granted by the 21 largest domestic banking institutions for energy conservation and environmental protection projects and services would decrease standard coal use by 282 million tons and reduce emissions of carbon dioxide by the equivalent of 567 million tons, ammonia nitrogen by 447,300 tons, sulfur dioxide by 7.45 million tons, and nitrogen oxides by 7.60 million tons. Chemical oxygen demand was expected to fall by 5.08 million tons. This green financing was also expected to reduce water use by 1.5 billion tons every year.

Green finance by bank size, purpose, and region. The green credit market is dominated by large and medium-sized banks (Figure 8), but the role of small banks is growing fast. The large bank green loan balance was CNY 7.18 trillion in 2019, up 14.1\% year-on-year and 1.3 percentage points below overall green finance credit market average growth. The numbers for medium-sized domestic banks were CNY1.67 trillion, and 1-year growth of 13.5\%, or 1.9 percentage points below the average. The green loan balance of small banks grew $32.8 \%$ in 1 year, 17.4 percentage points above the average, to CNY0.67 trillion. Renewable energy and clean projects (CNY4.47 trillion) and green transport projects (CNY2.49 trillion) accounted for $68.1 \%$ of the green loan balance and recorded 1 year growth rates of over $10 \%$. Over $83 \%$ of the overall loan balance went to infrastructure (CNY8.5 trillion), with the country's eastern region taking the largest share (CNY4.72 trillion) and having the fastest year-on-year growth at $16.1 \%$.

Figure 8: Distributions of Green Credit, 2019

(CNY trillion)

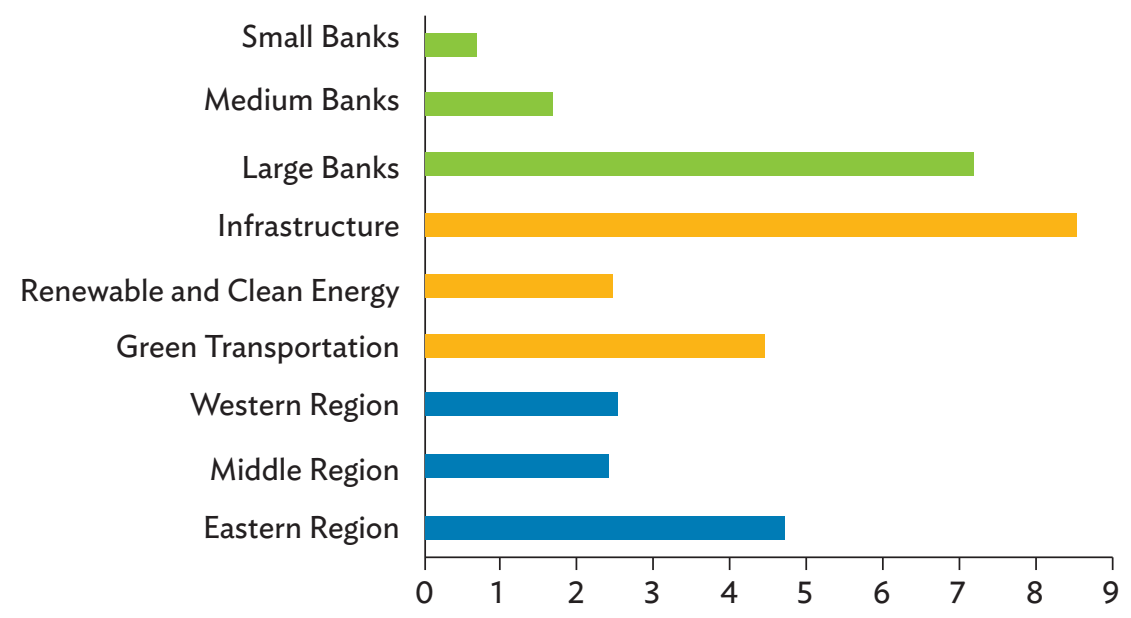

Source: People's Bank of China. 
Current obstacles. Despite the high volume of green finance by global standards, the PRC's green enterprises face a substantial financing gap to meet their obligations under the Paris Agreement and the PRC 2030 and 2060 carbon peak and neutrality targets. For instance, without strong policy and regulatory incentives, most banks are not compelled to develop specially tailored green finance products. Much of their profits come through traditional lending products and vehicles and banks are reluctant to venture into an unfamiliar sector, including the green credit sector. The challenging operating conditions, unstable cash flows, lack of collateral, and poorly understood business models that characterize small and medium-sized green enterprises are deterrents. The green finance guarantees provided by the PRC's government and international organizations are only demonstration pilots and the banking regulators have few meaningful incentives to offer. Action is also needed to promote green financing.

A positive step. One incentive that has shown results, however, has been the PBOC's inclusion since third quarter (Q3) 2017 of the green credit performance by 24 nationwide banks in its MPA system. This has effectively driven large national financial institutions, rural commercial banks, rural credit cooperatives, finance companies, urban commercial banks, and other financial institutions covered by the MPA to engage in more green credit businesses. By the end of June 2019 , the green loan balance of the 2,520 institutions participating in the assessment was growing at $6.38 \%$ quarterly or 3.66 percentage points faster than the national loan average.

\section{Green Securities}

The growth of green bonds. The market for green bonds, which with equity financing make up the green security sector in the PRC, has been expanding steadily in terms of the scale and diversity of its market players, fund investment areas and maturity and interest rate structure. The green bond market went from zero in 2015 to CNY230 billion in new issues in 2016, when it accounted for $40 \%$ of all such offerings globally. The cumulative value of PRC green bonds reached CNY1.1 trillion in 2019, making the market the second-largest in the world. Growth continued to be impressive, according to the PBOC, which reported CNY384.9 billion of green bond offerings by 168 domestic issuers in 2019, up 36.39\% on the previous year. The majority (303 valued at CNY300.1 billion) were issued onshore, with 24 bonds valued at CNY85.7 billion offered abroad by 14 issuers.

Diversity in issuers. Green bonds have been issued by industries outside the financial sector. Financial institutions continue to lead new issues and overall share of the market. In 2019, 23 banks and three financial leasing companies issued CNY83.3 billion worth of green bonds, bringing the cumulative value of the financial institution green bonds offered so far to CNY490.0 billion. The CNY83.2 billion of corporate green bonds issued during the year raised the total value so far of these corporate issues to CNY200.2 billion. The CNY47.3 billion in enterprise bond issues mainly supported transport and sewage treatment projects. Asset securitization, an important financing tool for green enterprises in the private sector, reached CNY50.0 billion. By 2019, the emerging market in exchangeable green bonds and municipal green bonds opened up another important channel for green finance. The breakdown of the bonds issued onshore in the PRC is provided in Figure 9.

Breakdown by sector. Industries from more sectors joined the mix of green bond issuers in 2019. The share of financial firms in new issues was down somewhat to $36 \%$, while those of industry (31\%) and utilities (23\%) were significantly up. Industries such as information technology, health care, and daily consumption entered the green bond market for the first time, and sectors in which green bond issues were supporting projects through lower financing costs and sustained financial support grew wider (Table 7). The funds in 2019 were mainly invested in six fields, with over two-thirds going into green services, green infrastructure upgrading, and clean energy (Table 8). 
Figure 9: Bonds Issued Onshore in the People's Republic of China, 2019

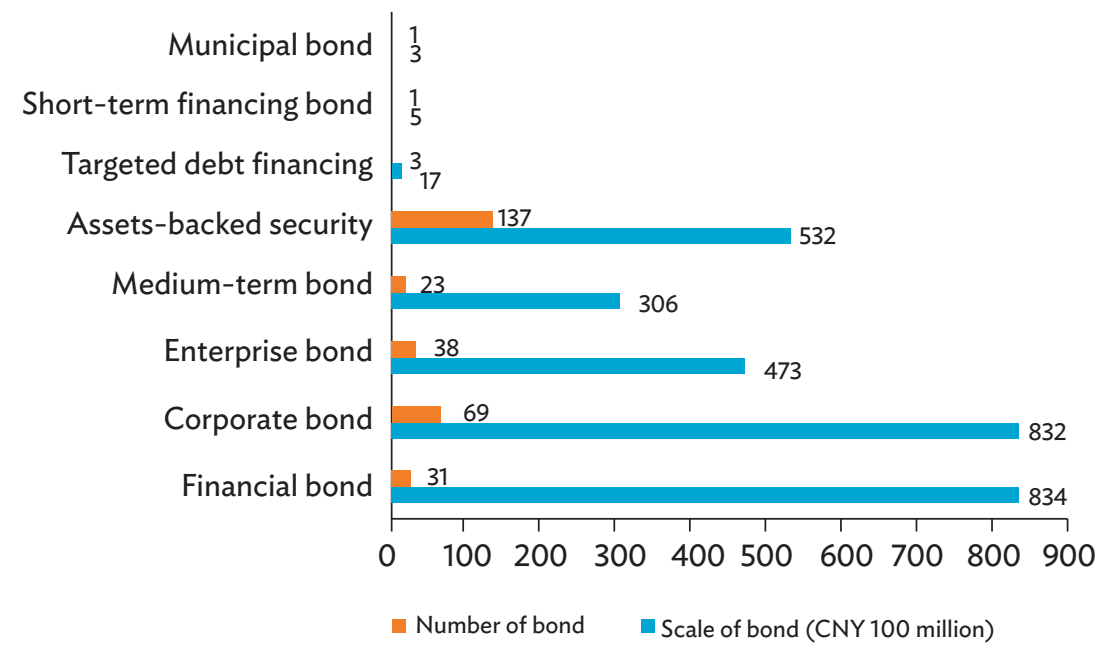

Source: People's Bank of China.

Table 7: Green Bonds Issued by Industry and Sector, 2019

\begin{tabular}{l|c|c|c|c}
\hline Industry & $\begin{array}{c}\text { Total Value } \\
\text { of Issues } \\
\text { (CNY100 million) }\end{array}$ & $\begin{array}{c}\text { Share of Value } \\
\text { of Issues Overall } \\
(\%)\end{array}$ & $\begin{array}{c}\text { Bonds } \\
\text { Issued } \\
\text { (No.) }\end{array}$ & $\begin{array}{c}\text { Share of Total } \\
\text { Number of Issues } \\
(\%)\end{array}$ \\
\hline Finance & 107.04 & 35.75 & 59 & 19.47 \\
\hline Industrial & 952.09 & 31.72 & 151 & 49.84 \\
\hline Utilities & 679.59 & 22.64 & 54 & 17.82 \\
\hline Energy & 73.4 & 2.45 & 3 & 0.99 \\
\hline Materials & 119.1 & 3.97 & 8 & 3.63 \\
\hline Optional Consumption & 67 & 2.23 & 5 & 2.64 \\
\hline Information Technology & 12 & 0.4 & 12 & 1.65 \\
\hline Health Care & 25.15 & 0.84 & 303 & 3.96 \\
\hline Total & $3,001.37$ & 100 & & 100 \\
\hline
\end{tabular}

CNY = yuan.

Source: Wind. https://www.wind.com.cn. 
Table 8: Green Bond Finance Investment Areas, 2019

\begin{tabular}{l|c|c}
\hline Investment Areas & $\begin{array}{c}\text { Bond Value } \\
\text { (CNY100 million) }\end{array}$ & $\begin{array}{c}\text { Bonds Issued } \\
\text { (No.) }\end{array}$ \\
\hline Energy Saving and Environmental Protection & 223.5 & 25 \\
\hline Clean Production & 102.65 & 23 \\
\hline Clean Energy & 752.99 & 57 \\
\hline Ecological Environment & 45.17 & 17 \\
\hline Green Infrastructure Upgrading & 804.02 & 122 \\
\hline Green Services & 1073.04 & 59 \\
\hline Total & $3,001.37$ & 303 \\
\hline
\end{tabular}

$\mathrm{CNY}=$ yuan.

Source: Wind. https://www.wind.com.cn.

Green equity finance outlook boosted by ongoing capital market development. The PRC is building a multitier capital market, including the main-board stock market, the Sci-Tech innovation board (STAR market), and a second-board market. This will help meet financing needs and diversify the sources of capital in the green industry sector. Green enterprises raised CNY52.8 billion in 2019 through IPOs and refinancing, 16 through CNY26.9 billion in IPOs and 18 via CNY25.9 billion in refinancing. The 17 green industry companies listed on the STAR market, which opened in 2018, include 6 related to new energy and 11 involved in the energy savings and environmental protection subsectors. More green companies that cannot meet the main board's conditions are expected to gain access to equity financing opportunities through listings on the STAR market in the future.

Greening of the equity market in progress. The government is simultaneously stepping up a program to promote environmental information disclosure by listed companies, an institutional reform first targeted by the China Securities Regulatory Commission in 2007. Progress so far has been slow. Over70\% oflisted companies did notpublishsuch disclosuresin2018, and governmentmonitoringassigned an overall average score of 40.69 on a scale of 100.00 for the quality of disclosures by the 76 that did. To raise participation in and the quality of environmental information disclosure, the PRC needs to impose stronger constraints and better incentives.

Green indexes for equities and bonds. Research and compilation for green indexing of equity and bond markets has also begun. The China Securities Index announced 13 thematic indexes in 2019, seven for stocks and six for bonds. These covered various aspects of ESG, the green industry, and environmental governance. The equity and bond value encompassed by the 46 green indexes and 19 index-tracking products under these themes totaled CNY9.6 billion. These indexes can help private capital make passive investments in groups of certifiably green listed companies, improve the valuations of these companies, reduce their financing costs, and generally boost green finance overall.

\section{Green Insurance}

Addressing high green industry risks. The heightened awareness of the need to protect the environment and the substantial technical challenges involved in doing so pose great market risks for green industries. Green insurance can reduce these risks and help cover potential economic losses over a long period. This, in turn, will encourage greater investment in the development and use of green technologies and facilities. The large volumes and lengthy investment cycles that characterize insurance funds can also provide the industry with long-term support.

Substantial growth. Environmental pollution liability insurance and energy insurance have been developing quickly. The former was piloted in 31 provinces in 2019 to cover 20 industries facing high 
environmental risks from activities in areas such as heavy metals and petrochemicals. Risk protection of CNY53.1 billion was extended to 15,700 enterprises. Insurance coverage had grown to CNY4 billion in the wind power sector, and CNY800 billion in nuclear, both fast-growing areas. Local governments are piloting green insurance in green building development in several regions and with some success in Beijing and Qingdao. For example, the People's Insurance Company of China has introduced green building performance insurance in Beijing to cover the risk that the expected results are not achieved. Qingdao's ultra-low energy consumption building performance insurance covers the downside risk should actual energy consumption by buildings exceed the expected range.

More growth and guidance needed. Nevertheless, the green insurance subsector remains small and still does not provide enough insurance products for green industries. Risk assessment and management capacity remain underdeveloped. Further advances in green insurance will require additional government guidance and more information and lessons from international green insurance businesses and products.

\section{Green Funds and Trusts}

Rapid development. By the end of 2019, there were 774 privately offered green funds and 74 greentheme mutual funds in the PRC with a total value of CNY60.7 billion. The 2019 Green Investment Self-Assessment Survey by the Asset Management Association of China had 378 valid responses and showed that privately offered funds demonstrated a high level of investment enthusiasm and strong foresight and incentives, while mutual funds featured stronger institutional development and staffing.

Government and development partner support. Governments and international organizations had supported the establishment of over 50 local green development funds or environmental protection funds in 16 provinces by the end of 2018. This support included green loans by the ADB to the Shandong Green Development Fund. Green funds backed by the Government of the PRC and international organizations can be a good way to leverage private capital into green industries and spur faster green finance development. Prefecture-level cities have also introduced green development funds. These generally raise financing for green urbanization or participation in public-private partnership (PPP) green funds. The number of green PPP projects implemented throughout the country reached 1,176 in 2017, with a total value of CNY1.3 trillion. The implementation rate was up 2 percentage points to 34\% from 2016 (Figure 10).

Figure 10: Development of Green Public-Private Partnership Projects

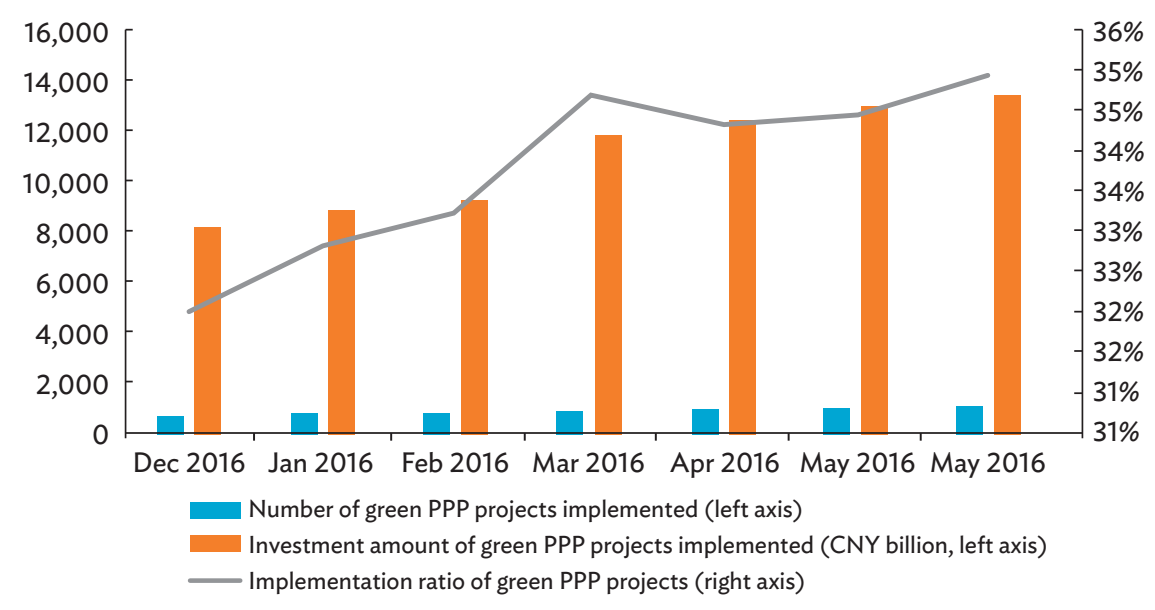

CNY = yuan, Dec = December, Feb = February, Jan = January, Mar = March, PPP $=$ public-private partnership. Source: Wind. https://www.wind.com.cn. 
A national fund. In 2020, the Ministry of Finance launched and became the biggest shareholder (11.30\%) in the first phase of the National Green Development Fund. CNY88.5 billion was raised from the 26 shareholders. These included the China Development Bank, People's Bank of China, China Construction Bank, Industrial and Commercial Bank of China, and Agricultural Bank of China, each holding 9.04\%; and Bank of China (8.47\%).

Green trusts. Twelve of the PRC's trust companies have set up business departments to develop green investment projects since 2013. These green trusts had invested CNY132.6 billion in 413 green projects by the end of 2018, of which non-credit instruments accounted for $48 \%$, using diverse business models and products (Figure 11). Over 60\% of the funds were invested in clean energy and infrastructure upgrading, and 30\% in ecological environment and energy savings and environmental protection. Trusts, which have the most flexible asset allocation among the financial systems and excellent wealth management, are expected to become an important capital force in green finance.

Figure 11: Green Trust Financing, 2013-2018

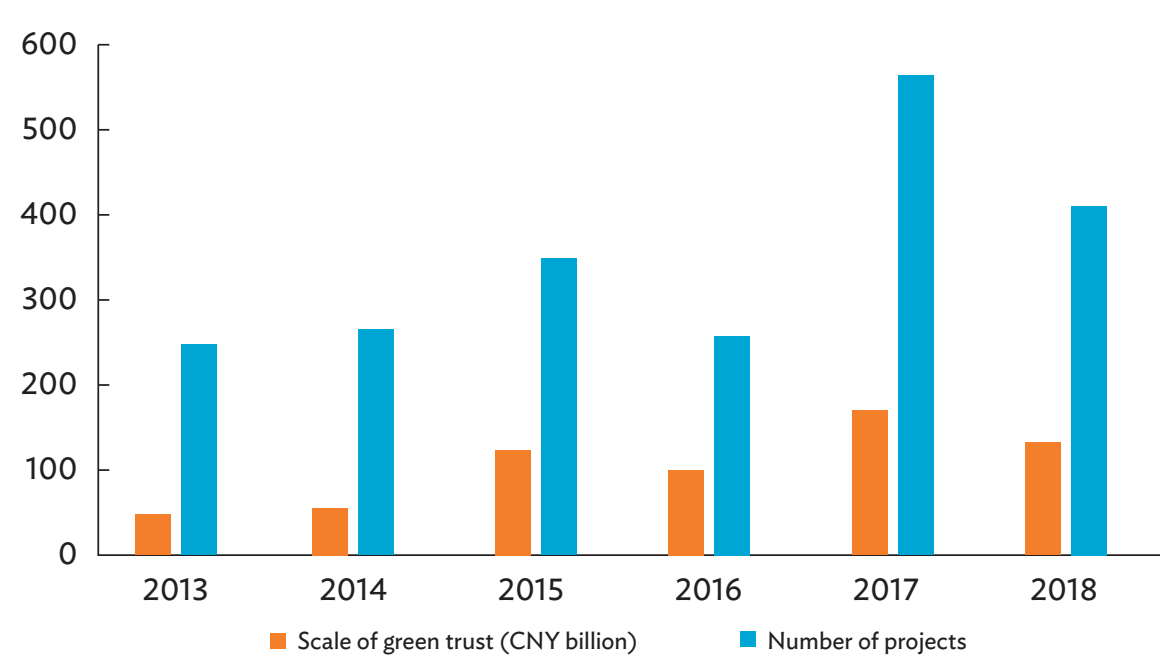

CNY = yuan.

Source: China Trustee Association.

\section{Green Guarantees}

Countering risk aversion. Guarantee mechanisms can reduce the risks perceived by financial institutions in green enterprises due to the lack of collateral and credit histories, poor cash flows, long payback terms, and business models and plans that traditional investors tend to avoid. Even a comparatively small amount of government-backed guarantees can attract nongovernment investors to projects that will further public goods. Guarantees by the PRC's governments for such green undertakings, however, remain imperfect and still very small.

A guarantee of success. An example of the potential for successful leverage and sustainable long-term use and benefits from green guarantees comes from the broad China Energy Conservation Promotion Project supported by the World Bank and the Global Environment Fund. The governmentsupported China National Investment \& Guaranty Corporation (I\&G) provided guarantees for Phase II of the project, which completed 148 projects in 22 provinces and municipalities over 6 years of 
implementation that ended in 2009. Investments in the projects totaled CNY900 million, guaranteed loans CNY500 million, and I\&G's guarantee reserves only CNY150 million. As a result, I\&G leveraged 3.82 times the loan amount and 6.06 times the investment amount. The income from guarantee fees and interest basically equaled the expenditures for loss of compensation and management fees. The remaining guarantee reserves principal can be rolled over to generate leverage investments and lending for the next phase of the project.

The need for change in institutions, structures, awareness, and attitudes. The green industry is indispensable to upgrading and transforming the PRC's economy, but is unlikely to attract greater capital investment without help. The government needs to create favorable policies and supportive institutional environments to offset the challenges and risks the industry presents. Because green industry confronts prospective investors with long payback periods, uncertain payback ratios, and room for poor or deceptive planning, authorities need to strengthen supervision and disclosure in the industrial sector overall. Action is also needed on the supply side through education of investors on green industry projects and plans and the significance of investments in sustainable development over the long term. The government should also build a strong green finance system that links investors with green industries in need of capital and financing. The government can also guide financial institutions in researching and designing exclusive instruments for green finance by using traditional financial supplies to leverage capital on a layer-bylayer basis. The PRC can absorb some international capital in green industry investments and the latest experience abroad in management and operations.

\section{CONCLUSIONS AND IMPLICATIONS FOR FURTHER FINANCIAL REFORMS}

Financial sector reform and road map. The PRC's 40 years of economic reform have led to a sophisticated and comprehensive financial system. Moving forward, the financial system needs reform to help fulfil the country's innovation-oriented development strategy. The Third Plenum of the Eighteenth National Party Congress outlined a blueprint for future financial reforms in $2013 .{ }^{7}$ It covered three broad areas: lowering entry barriers, emphasizing market mechanisms, and improving financial regulation. In terms of lowering entry barriers, the PRC planned to (i) open the financial system internally and externally and allow the establishment of financial institutions such as small and mediumsized private banks; (ii) reform policy banks; (iii) develop multilayer capital markets and increase direct financing; (iv) improve insurance and economic compensation systems; (v) foster inclusive finance; and (vi) encourage financial innovation and enrich the layers and products of financial markets. In terms of freeing market mechanisms, the PRC planned to (i) improve interest rate and exchange rate mechanisms and form a government bond yield curve, (ii) promote the two-way opening of capital markets, and (iii) accelerate capital account convertibility. In terms of improving financial regulation, the PRC planned to (i) implement financial regulatory measures and prudential standards; (ii) establish a deposit insurance system and improve the capital market exit mechanism; and (iii) strengthen the development of financial infrastructure. All these steps are designed to ensure the efficient operation and stability of the financial system.

The 14th Five-Year Year Plan (2021-2025) for National Economic and Social Development of the PRC outlined a development strategy that supports the harmonious coexistence between people and nature through the improvement of ecosystem quality and sustainability and green transformation

7 People's Daily. 2013. Fully Deepen the financial Sector Reform and Facilitate Financial Markets System (in Chinese language). Beijing. 
and development. At the same time, the PRC continues to support improvements in financial sector development and regulation. The PRC will improve financial innovations and develop advanced financial technologies, such as patent and trademark pledge finance. The PRC also plans to liberalize the domestic listing requirement for technology companies in capital markets and promote "hard technology." In terms of financial regulations, the PRC will continue to modernize its financial regulatory system, for example, by promoting financial innovations in the tech sector in an orderly manner under the premise of prudential supervision, widening regulatory risk coverage (framework), and improving financial regulatory transparency. Regulatory agencies will also strengthen the use of regulatory technologies and risk assessment tools for financial innovation and explore the establishment of market correction and suspension mechanisms.

Alignment with ADB Strategy. ADB's new PRC CPS (2021-2025) aligns with the 14th Five-Year Plan (2021-2025) for National Economic and Social Development of the PRC in areas of environmental sustainability, climate change mitigation and adaptation, and aging society and health security. ADB will continue to support these government initiatives in part through financial sector development programs as outlined above, which aim to support the PRC's transition through a high-quality development model. Within this context, continued reforms in the PRC financial sector will facilitate ADB's engagement in the country.

Gradual reforms likely in four broad areas. Reforms can continue gradually in the following four broad areas.

Motivating financial innovation. The PRC should further increase the share and role of direct financing. Equity investments, including investment via stock markets and by venture capital and private equity firms, are important for developing the ground-breaking innovation and major technological advances and inventions the PRC's financial system and transitioning economy requires. The current IPO approval process can be improved with a less restricted registration system and a more liberal exit mechanism to enhance the liquidity and efficiency of the country's equity market. Commercial banks should transform themselves by fully adopting digital technologies to improve their efficiency and reduce their costs. Regulatory authorities should create a more favorable environment for innovations in digital finance that will broaden financial inclusion.

Pursuing further financial openness. The steps taken toward financial openness in the PRC have included providing greater foreign access to the financial service sector, liberalizing the capital account, and restarting the internationalization of the yuan. Capital inflows into the system might exceed capital outflows and alleviate domestic financial constraints and help smooth investment. The government should aim for further openness in the capital account while still paying attention to potentially adverse consequences. A flexible exchange rate regime should be achieved alongside the introduction of macro prudential policies to reduce volatility caused by large volumes of short-term cross-border capital flows (Huang and Wang 2020). In terms of financial market liberalization, the government should push ahead with market-oriented financial reforms. The implicit government guarantees that have supported financial stability in the past may no longer be sustainable. The market should be allowed to better determine prices in the financial system. This includes interest and exchange rates and bond yields. The financial market should also determine the allocation of financial resources, which will require greater liberalization in bank credit, issuing bonds, initial public offerings, and even crossborder capital flows. This also includes steps to complete interest rate liberalization, achieve a floating exchange rate, facilitate cross-border movement of capital, and lower entry barriers for both private and

8 In the PRC context, "hard tech" is defined as core technologies that require long-term research and development and continuous efforts and investment, such as optoelectronic chips, artificial intelligence, aerospace, biotechnology, information technology, new materials, new energy, and smart manufacturing. 
foreign financial institutions. The government should support a market-clearing mechanism that allows any nonviable enterprise, whatever its ownership, to default, go bankrupt, or shut down. The PRC could consider promotion of ownership neutrality to encourage market competition.

Improving financial regulation. The PRC needs more efficiency and enforcement in its financial system regulation. Further reforms should ensure that regulatory authorities set clear policies and seek accountability when these are not followed. The government should also give regulators greater autonomy and authority. Different financial supervision methods have different advantages, and weaknesses could be exposed by not fully reflecting the fact that financial institutions are engaging in more universal financial operations. The government should consider following up on the adjustments made to the supervision framework so far to enact regulation based not on the legal status of individual financial institutions, but on their financial functions and operations. Conduct-of-business regulation also needs to be strengthened. 


\section{REFERENCES}

Abiad, A., E. Detragiache, and T. Tresse. 2008. A new database of financial reforms. International Monetary Fund Working Paper. No. 2008-2266. Washington, DC: International Monetary Fund.

Ang, J.B. and W.J. McKibbin. 2007. Financial Liberalization, Financial Sector Development and Growth: Evidence from Malaysia. Journal of Development Economics. 84. pp. 215-233.

Brown, J.R., S.M. Fazzari, and B.C. Petersen. 2009. Financing Innovation and Growth: Cash Flow, External Equity, and the 1990s R\&D Boom. Journal of Finance. 64. pp. 151-185.

Brown, J.R., G. Martinsson, and B.C. Petersen. 2013. Law, Stock Markets, and Innovation. Journal of Finance. 68. pp. 1517-1549.

Cai, F., Z. Li., and J. Lin. 1995. The China Miracle: Development Strategy and Economic Reform. The Chinese University of Hong Kong Press, Hong Kong.

Gambacorta, L., et al. 2019. How do machine learning and non-traditional data affect credit scoring? New evidence from a Chinese fintech firm. BIS Working Paper. No. 834. Hong Kong, China: Bank for International Settlements.

Godwin, A., L. Guo, and I. Ramsay. 2016. Is Australia's Twin Peaks System of Financial Regulation a Model for China? CIFR Research Paper. No. 102/2016. Sydney, Australia: Centre for International Finance and Regulation.

Gou, Q., Y. Huang, and X. Wang. 2014. Financial liberalization and the middle-income trap: What can China learn from the cross-country experience? China Economic Review 31 (2014): 426-440.

Hellmann, T., K. Murdock, and J. Stiglitz. 1997. Financial Restraint: Toward a New Paradigm. In M. Aoki, H.K. Kim and M. Okuno-Fujuwara, eds. The Role of Government in East Asian Economic Development: Comparative Institutional Analysis. Oxford: Clarendon Press. pp. 163-207.

Hellmann, T., K. Murdock, and J. Stiglitz. 2000. Liberalization, Moral Hazard in Banking and Prudential Regulation: Are Capital Controls Enough? American Economic Review. Vol. 90. pp. 147-165.

Hsu, P., X. Tian, and Y. Xu. 2014. Financial Development and Innovation: Cross Country Evidence. Journal of Financial Economics. 112. pp. 116-135.

Huang, Y. 2001. Last Steps Across the River: Enterprise and Banking Reform in China. Canberra: Asia Pacific Press.

Huang, Y. and X. Wang. 2011. Does Financial Repression Inhibit and Facilitate Economic Growth: A Case Study of China's Reform Experience. Oxford Bulletin of Economics and Statistics. 73.6 (2011). pp. 833-855.

Huang Y. and X. Wang. 2017. Reforming China's Financial Supervision System. Unpublished Working Paper. Beijing: Peking University National School of Development.

Huang, Y. and X. Wang. 2017. Building an Efficient Financial System in China: The Need for Market Discipline. Asian Economic Policy Review. 12.2 (2017). pp. 188-205. 
Huang Y. and X. Wang. 2018. Managing Systemic Financial Risks in China. Unpublished Working Paper. Beijing: Peking University National School of Development.

Huang, Y. and X. Wang. 2020. Financial Liberalization and Corporate Investment: Cross Country Evidence. Working Paper. Beijing: Peking University National School of Development.

Huang, Y. and X. Wang. 2020. Mobile Payment in China: Practice and Its Effects. Asian Economic Papers. Vol. 19. No. 3. pp.1-18.

Huang, Y., et al. 2013. Financial Reform in China: Progress and Challenges. In Yung Chul Park and Hugh Patrick, eds. How Finance Is Shaping the Economies of China, Japan and Korea. New York: Columbia University Press.

Jagtiani, J. and C. Lemieux. 2019. The Roles of Alternative Data and Machine Learning in Fintech Lending: Evidence from the Lending Club Consumer Platform. Financial Management. 48 (4):1009-1029.

Kajole, N. and M. Kaur. 2016. Financial Inclusion and Human Development: A Cross-country Evidence. Management and Labour Studies 41(2): 127-153.

King, R.G. and R. Levine. 1993. Finance, Entrepreneurship and Growth: Theory and Evidence. Journal of Monetary Economics. Vol. 32. pp. 513-542.

Klein, A. 2019. Is China's New Payment System the Future? Washington, DC: Brookings Institution.

Lane, P.R. and G.M. Milesi-Ferretti. 2007. The External Wealth of Nations Mark II. Journal of International Economics. Vol. 73. pp. 223-250.

Laurenceson, J. and J.C.H. Chai. 2003. Financial Reform and Economic Development in China. Cheltenham: Edward Elgar.

Levine, R. 2005. Finance and growth: theory, mechanisms and evidence. in P. Aghion and S.N. Durlauf, eds. Handbook of Economic Growth. Amsterdam: North-Holland.

McKinnon, R.I. 1973. Money and Capital in Economic Development. Washington, DC: The Brookings Institution.

Naughton, B. 1995. Growing Out of the Plan: Chinese Economic Reform 1978-1993. Cambridge: Cambridge University Press.

Pagano, M. 1993. Financial Markets and Growth: An Overview. European Economic Review. Vol. 37. pp. 613-622.

Roubini, M. and X. Sala-i-Martin. 1992. Financial Repression and Economic Growth. Journal of Development Economics. 39. pp. 5-30.

Shaw, A.S. 1973. Financial Deepening in Economic Development. New York: Oxford University Press.

Stiglitz, J. 1994. The Role of the State in Financial Markets. In M. Bruno and B. Pleskovic, eds. Proceeding of the World Bank Annual Conference on Development Economics, 1993: Supplement to the World Bank Economic Review and the World Bank Research Observer. Washington, DC: World Bank. pp. 19-52.

Stiglitz, J. 2000. Capital Market Liberalization, Economic Growth and Instability. World Development. 28. pp. 1075-1086. 
Stiglitz, J. and A. Weiss. 1981. Credit Rationing in Markets with Imperfect Information. American Economic Review. Vol. 71. pp. 393-410.

Wang, B. and T. Sun. 2013. How effective are macroprudential policies in China? International Monetary Fund Working Paper. No.75. Washington, DC: International Monetary Fund.

Wang, X. 2020. Access to Finance and Innovation. Working Paper. Beijing: Peking University National School of Development.

Wang, X. 2020. Financing Innovation in China. East Asia Forum. 29 December. https://www.eastasiaforum. org/2020/12/29/financing-innovation-in-china/.

Wang, X. 2020. Openness, Growth Convergence and China's Development Prospects. China Economic Journal. Vol. 13. No. 1. pp. 82-108.

World Bank. 2014. Digital Finance: Empowering the Poor via New Technologies. April 10. https://www.worldbank.org/en/news/feature/2014/04/10/digital-finance-empowering-poor-newtechnologies. Accessed on February 18, 2020.

Yi, G. 2009. On the Financial Reform of China. Beijing: The Commercial Press. 


\section{Promoting High-Quality Growth Through Financial Reform in the People's Republic of China}

The People's Republic of China (PRC) has achieved record economic growth since initiating reform policies in the late 1970s. Success has been attributed, in part, to the expansion and development of the financial system led by large state-owned banks. The resulting financial system stability and increasing sophistication paved the way for the economic prosperity we see today. From the 2010s, the PRC's economic landscape and government priorities began to change, shifting to higher quality growth through technological advancement, financial inclusiveness, innovation and environmental sustainability, as reflected in the recent rise in digital and green finance.

To maintain economic efficiency and a high growth trajectory, the PRC needs to continue its economic transition and deepen financial sector reform through measures such as gradually opening up financial markets to foreign and domestic private capital to finance new emerging sectors, strengthening regulatory and supervisory regimes in the face of rapid technological changes and promoting financial innovations. These efforts will support the PRC's 14th Five-Year Plan (2021-2025) for green and high-quality economic and social development.

\section{About the Asian Development Bank}

ADB is committed to achieving a prosperous, inclusive, resilient, and sustainable Asia and the Pacific, while sustaining its efforts to eradicate extreme poverty. Established in 1966, it is owned by 68 members -49 from the region. Its main instruments for helping its developing member countries are policy dialogue, loans, equity investments, guarantees, grants, and technical assistance. 